\title{
Investigation of the oxidation of methyl vinyl ketone (MVK) by OH radicals in the atmospheric simulation chamber SAPHIR
}

\author{
Hendrik Fuchs $^{1}$, Sascha Albrecht ${ }^{1}$, Ismail-Hakki Acir ${ }^{1, a}$, Birger Bohn ${ }^{1}$, Martin Breitenlechner ${ }^{2}$, Hans-Peter Dorn ${ }^{1}$, \\ Georgios I. Gkatzelis ${ }^{1}$, Andreas Hofzumahaus ${ }^{1}$, Frank Holland ${ }^{1}$, Martin Kaminski ${ }^{1, b}$, Frank N. Keutsch ${ }^{2}$, \\ Anna Novelli ${ }^{1}$, David Reimer ${ }^{1}$, Franz Rohrer ${ }^{1}$, Ralf Tillmann ${ }^{1}$, Luc Vereecken ${ }^{1}$, Robert Wegener ${ }^{1}$, \\ Alexander Zaytsev ${ }^{2}$, Astrid Kiendler-Scharr ${ }^{1}$, and Andreas Wahner ${ }^{1}$ \\ ${ }^{1}$ Institute of Energy and Climate Research, IEK-8: Troposphere, Forschungszentrum Jülich GmbH, Jülich, Germany \\ ${ }^{2}$ School of Engineering and Applied Sciences and Department of Chemistry and Chemical Biology, Harvard University, \\ Cambridge, MA, USA \\ anow at: Institute of Nutrition and Food Sciences, Food Chemistry, University of Bonn, Germany \\ ${ }^{b}$ now at: Bundesamt für Verbraucherschutz, Abteilung 5 - Methodenstandardisierung, Berlin, Germany
}

Correspondence: Hendrik Fuchs (h.fuchs@fz-juelich.de)

Received: 12 March 2018 - Discussion started: 19 March 2018

Revised: 18 May 2018 - Accepted: 23 May 2018 - Published: 7 June 2018

\begin{abstract}
The photooxidation of methyl vinyl ketone (MVK) was investigated in the atmospheric simulation chamber SAPHIR for conditions at which organic peroxy radicals $\left(\mathrm{RO}_{2}\right)$ mainly reacted with $\mathrm{NO}$ ("high NO" case) and for conditions at which other reaction channels could compete ("low NO" case). Measurements of trace gas concentrations were compared to calculated concentration time series applying the Master Chemical Mechanism (MCM version 3.3.1). Product yields of methylglyoxal and glycolaldehyde were determined from measurements. For the high NO case, the methylglyoxal yield was $(19 \pm 3) \%$ and the glycolaldehyde yield was $(65 \pm 14) \%$, consistent with recent literature studies. For the low NO case, the methylglyoxal yield reduced to $(5 \pm 2) \%$ because other $\mathrm{RO}_{2}$ reaction channels that do not form methylglyoxal became important. Consistent with literature data, the glycolaldehyde yield of $(37 \pm 9) \%$ determined in the experiment was not reduced as much as implemented in the MCM, suggesting additional reaction channels producing glycolaldehyde. At the same time, direct quantification of $\mathrm{OH}$ radicals in the experiments shows the need for an enhanced $\mathrm{OH}$ radical production at low $\mathrm{NO}$ conditions similar to previous studies investigating the oxidation of the parent VOC isoprene and methacrolein, the second major oxidation product of isoprene. For MVK the model-measurement discrepancy was up to a factor of 2 . Product yields and $\mathrm{OH}$ observations were consistent with
\end{abstract}

assumptions of additional $\mathrm{RO}_{2}$ plus $\mathrm{HO}_{2}$ reaction channels as proposed in literature for the major $\mathrm{RO}_{2}$ species formed from the reaction of $\mathrm{MVK}$ with $\mathrm{OH}$. However, this study shows that also $\mathrm{HO}_{2}$ radical concentrations are underestimated by the model, suggesting that additional $\mathrm{OH}$ is not directly produced from $\mathrm{RO}_{2}$ radical reactions, but indirectly via increased $\mathrm{HO}_{2}$. Quantum chemical calculations show that $\mathrm{HO}_{2}$ could be produced from a fast $1,4-\mathrm{H}$ shift of the second most important $\mathrm{MVK}$ derived $\mathrm{RO}_{2}$ species (reaction rate constant $0.003 \mathrm{~s}^{-1}$ ). However, additional $\mathrm{HO}_{2}$ from this reaction was not sufficiently large to bring modelled $\mathrm{HO}_{2}$ radical concentrations into agreement with measurements due to the small yield of this $\mathrm{RO}_{2}$ species. An additional reaction channel of the major $\mathrm{RO}_{2}$ species with a reaction rate constant of $(0.006 \pm 0.004) \mathrm{s}^{-1}$ would be required that produces concurrently $\mathrm{HO}_{2}$ radicals and glycolaldehyde to achieve modelmeasurement agreement. A unimolecular reaction similar to the $1,5-\mathrm{H}$ shift reaction that was proposed in literature for $\mathrm{RO}_{2}$ radicals from MVK would not explain product yields for conditions of experiments in this study. A set of $\mathrm{H}$-migration reactions for the main $\mathrm{RO}_{2}$ radicals were investigated by quantum chemical and theoretical kinetic methodologies, but did not reveal a contributing route to $\mathrm{HO}_{2}$ radicals or glycolaldehyde. 


\section{Introduction}

Isoprene $\left(\mathrm{C}_{5} \mathrm{H}_{8}\right)$ emitted by plants (Guenther et al., 2012) has the highest emission rate among non-methane organic compounds. Isoprene is mainly oxidised by the photochemically generated hydroxyl radical $(\mathrm{OH})$ forming the first-generation organic compounds methacrolein (MACR), methyl vinyl ketone (MVK), formaldehyde (HCHO and isoprene hydroxyperoxides (ISOPOOH) (e.g. Karl et al., 2006). The latter ones are formed without the involvement of nitric oxide (NO) so that ISOPOOH becomes increasingly important with decreasing concentrations of nitrogen oxides (St. Clair et al., 2015) which are mainly released by anthropogenic activities. The formation of MVK and MACR is accompanied by the production of $\mathrm{HO}_{2}$, which can further recycle $\mathrm{OH}$, whereas ISOPOOH formation is a radical termination reaction. However, field studies have shown that also in environments where NO concentrations are less than a few 100 pptv a high $\mathrm{OH}$ regeneration rate can be maintained which is not explained by chemical models (Tan et al., 2001; Lelieveld et al., 2008; Hofzumahaus et al., 2009; Whalley et al., 2011). The gap between measured and modelled $\mathrm{OH}$ is correlated with the abundance of isoprene (Lu et al., 2012). Since then, it has been recognised that organic peroxy radical $\left(\mathrm{RO}_{2}\right)$ pathways which do not require $\mathrm{NO}$ as reaction partner can also significantly recycle $\mathrm{OH}$ (Wennberg et al., 2018). These reactions include

- hydrogen-shift reactions of $\mathrm{RO}_{2}$ radicals forming $\mathrm{OH}$ or $\mathrm{HO}_{2}$,

- reaction of peroxy radicals with $\mathrm{HO}_{2}$.

These pathways have both been identified in the oxidation chain of isoprene (Peeters et al., 2009; Peeters et al., 2014). A $1,6 \mathrm{H}$-shift of $\mathrm{RO}_{2}$ formed in the reaction of isoprene with $\mathrm{OH}$ leads to the formation of hydroxyperoxy aldehydes (HPALD) and $\mathrm{HO}_{2}$. The photolysis of HPALD gives even additional $\mathrm{OH}$ radicals. Its relevance for the atmosphere has been shown in laboratory experiments (Crounse et al., 2011; Wolfe et al., 2012) and chamber experiments (Fuchs et al., 2013). In the supplement of the first publication of the LIM (Peeters et al., 2009) the authors also suggested that a 1,5-Hshift reaction could be relevant for MVK and MACR. However, for MACR a 1,4 $\mathrm{H}$-shift reaction for $\mathrm{RO}_{2}$ was found, which efficiently recycles OH (Crounse et al., 2012). Its impact on the radical budget has been shown in chamber experiments (Fuchs et al., 2014). H-shift reactions have also been proposed to be important for $\mathrm{RO}_{2}$ radicals which are formed in the oxidation chain of ISOPOOH (D'Ambro et al., 2017) also potentially enhancing the $\mathrm{OH}$ regeneration rate.

The reaction of peroxy radicals with $\mathrm{HO}_{2}$ forms not only hydroxyperoxides, but also $\mathrm{OH}$ together with an alkoxy radical. This was shown for the acetylperoxy radical with an $\mathrm{OH}$ yield of $50 \%$ (Dillon and Crowley, 2008; Winiberg et al., 2016). In a recent study by Praske et al. (2015), product yields from the reaction of MVK derived peroxy radicals with $\mathrm{HO}_{2}$ were investigated. Similar to the acetylperoxy radical, product yields demonstrated that only one third of the reaction yields hydroxyperoxides and that two additional reaction channels exist, both of which could lead to the reformation of $\mathrm{OH}$.

In this study, the oxidation of MVK by $\mathrm{OH}$ was investigated in the atmospheric simulation chamber SAPHIR (Simulation of Atmospheric Photochemistry In a Large Reaction Chamber) at Forschungszentrum Jülich. Experiments were performed under controlled conditions with atmospheric trace gas and radical concentrations. In these experiments, not only organic compounds like in previous studies were measured, but also radical species $\left(\mathrm{OH}, \mathrm{HO}_{2}\right.$, and $\left.\mathrm{RO}_{2}\right)$ allowing for an analysis of the $\mathrm{OH}$ budget. In the low $\mathrm{NO}$ case, NO mixing ratios were kept below 100 pptv so that different $\mathrm{RO}_{2}$ radical reactions, i.e. reaction with $\mathrm{HO}_{2}$ and unimolecular isomerisation reactions, can compete. Measured time series of radical concentrations are compared to model calculations applying the Master Chemical Mechanism version 3.1.1 (MCM, 2017) and modifications suggested in literature.

\section{Methods}

\subsection{Simulation experiment in SAPHIR}

Experiments were performed in the outdoor atmospheric simulation chamber SAPHIR. Details of the chamber can be found in previous publications (e.g. Rohrer et al., 2005). SAPHIR has a cylindrical shape (length $18 \mathrm{~m}$, diameter $5 \mathrm{~m}$, volume $270 \mathrm{~m}^{3}$ and consists of a double-wall FEP (fluorethylene-propylene) film. A small overpressure (45 Pa) prevents ambient air entering the chamber. The replenishment flow that is required to maintain this pressure leads to a dilution of all trace gases by approximately 3 to $5 \%$ per hour. A shutter system shades the chamber before the photooxidation experiment is started. Natural sunlight is used to irradiate the mixture. Small sources of nitrous acid (HONO) and formaldehyde $(\mathrm{HCHO})$ are present in the sunlit chamber (100 to $200 \mathrm{pptv} \mathrm{h}^{-1}$ ). The photolysis of HONO is typically the primary source for $\mathrm{OH}$ radicals and nitrogen oxides.

In total, four experiments were conducted in this study, two of them at low NO (23 June 2016: NO $<70$ pptv and 23 May 2017: $\mathrm{NO}<40 \mathrm{pptv}$ ) and two of them at high NO conditions (20 August 2014: 0.7 to $6 \mathrm{ppbv}$ NO and 17 May 2017: approximately 0.1 to 0.4 ppbv NO). Results from experiments performed at similar conditions gave consistent results. The discussion of results focuses on the two experiments for which the number of trace gas measurements was highest and results for the other experiments are shown in the Supplement.

The experiments started with cleaning the chamber air by flushing out impurities from previous experiments until trace 
gas concentrations were below the detection limit of the instruments. The chamber air was first humidified by flushing water vapour from boiling water into the dark chamber (relative humidity approximately $70 \%$ ). In the low NO experiments, approximately $140 \mathrm{ppbv}$ ozone produced from a silent discharge ozoniser (O3onia) was injected in the dark in order to suppress NO concentrations. In contrast, 6 to $10 \mathrm{ppbv}$ of $\mathrm{NO}_{2}$ or $\mathrm{NO}$ were injected from a gas mixture in case of the high NO experiments. In one of the two low NO experiments (23 May 2017), 20 ppbv MVK (Sigma-Aldrich, purity 99\%) in water was injected in the dark chamber from a Liquid Calibration Unit (LCU, Ionicon). MVK (1.5 ppbv) was reinjected after $3.5 \mathrm{~h}$ of photooxidation. In the other experiments, MVK was injected several times during the experiment after an initial phase of illumination of the chamber air without additional $\mathrm{OH}$ reactants by injecting liquid $\mathrm{MVK}$ into a heated inlet line that is flushed by synthetic air. This procedure was similar to that applied in previous studies (e.g. Fuchs et al., 2013, 2014; Kaminski et al., 2017). The photooxidation of MVK was then observed for several hours. No significant particle formation was observed in the experiments so that only gas-phase chemistry needs to be considered in the evaluation.

\subsection{Instrumentation}

Trace gas concentrations were measured with a comprehensive set of instruments. Nitric oxide (NO) was detected by chemiluminescence (Eco Physics) and nitrogen dioxide $\left(\mathrm{NO}_{2}\right)$ by the same instrument but with a blue-light converter in the inlet. In one of the experiments (17 May 2017), no $\mathrm{NO}_{x}$ measurements were available. A cavity ring-down instrument (Picarro) monitored water vapour and carbon monoxide and a UV photometer (Ansyco) detected ozone.

The total $\mathrm{OH}$ reactivity (inverse lifetime of $\mathrm{OH}$ ) was measured by a pump-probe method (Lou et al., 2010; Fuchs et al., 2017), in which the decay of $\mathrm{OH}$ radicals produced by laser flash photolysis of ozone is observed by laser-induced fluorescence (LP-LIF). OH reactivity gives a measure of all $\mathrm{OH}$ reactant concentrations, so that potential gaps in the detection of e.g. organic compounds that are relevant for the radical chemistry can be identified (e.g. Nölscher et al., 2012). Unfortunately, the instrument failed in 2014, thus $\mathrm{OH}$ reactivity was only measured in one of the two high NO experiments.

Organic compounds were measured by a proton-transfer time-of-flight mass spectrometer (PTR-TOF-MS, Ionicon), which was calibrated to quantify MVK. Methylglyoxal $\left(\mathrm{CHOCOCH}_{3}, \mathrm{MGLYOX}\right)$, and glycolaldehyde $\left(\mathrm{HOCH}_{2} \mathrm{CHO}\right)$ were quantified in one low and one high NO experiment. In the other two experiments, performed in different years, the PTR-TOF-MS was calibrated for MVK, but not for methylglyoxal and glycolaldehyde for all experiments so that these species could not be quantified in all experiments. Acetic acid was detected on the same mass as glycolaldehyde in the PTR-TOF-MS instrument. However, model calculations suggest that the contribution of acetic acid was less than $10 \%$ of the total signal. Therefore, measurements represent glycolaldehyde concentrations reasonably well.

A second PTR-TOF-MS instrument (PTR-3, Ionicon) quantified MVK concentrations in the experiment on 23 May 2017. Measurements of both instruments agreed within $20 \%$. In addition to direct measurements of MVK concentrations, measurements of the $\mathrm{OH}$ reactivity can be used to calculate the MVK concentration that was injected in the experiments because the increase in $\mathrm{OH}$ reactivity at that point in time can be attributed to the MVK concentration increase. The comparison with the increase in MVK measurements by the PTR-TOF-MS instrument shows good agreement.

In the experiments in 2017 , formaldehyde was measured by the same differential optical absorption spectroscopy (DOAS) instrument that also detects $\mathrm{OH}$ radicals in the chamber (Dorn et al., 1995). In the other years, HCHO was measured by a Hantzsch monitor. The $1 \sigma$-precision of the formaldehyde measurement of $230 \mathrm{pptv}$ is less than that of the Hantzsch monitor (20 pptv), but it is sufficiently high for the detection of HCHO in the experiments here.

$\mathrm{OH}$ was detected by DOAS (Dorn et al., 1995) in all experiments except for the high NO experiment in 2014. In addition, $\mathrm{OH}, \mathrm{HO}_{2}$ and $\mathrm{RO}_{2}$ radicals were measured by laserinduced fluorescence (LIF). The instrument has been described in detail elsewhere (Fuchs et al., 2008, 2011; Fuchs et al., 2016). OH concentrations measured by LIF in the SAPHIR chamber have been shown to agree with measurements by DOAS in several comparison exercises (e.g. Schlosser et al., 2009; Fuchs et al., 2012). Good agreement was also observed in this work so that significant potential artefacts in the LIF detection scheme as reported for some instruments in the field (Mao et al., 2012; Novelli et al., 2014; Rickly and Stevens, 2018) can be excluded.

$\mathrm{HO}_{2}$ and $\mathrm{RO}_{2}$ are chemically converted to $\mathrm{OH}$ by the reaction with $\mathrm{NO}$ prior to $\mathrm{OH}$ detection by laser-induced fluorescence in the LIF instrument. The conversion of $\mathrm{RO}_{2}$ requires at least two subsequent reactions with NO. First, $\mathrm{RO}_{2}$ is converted through adding $\mathrm{NO}$ to $\mathrm{HO}_{x}$ in a flow reactor upstream of the fluorescence cell. Added CO in the reactor ensures that the $\mathrm{HO}_{x}$ consists predominantly of $\mathrm{HO}_{2}$, which has a small wall loss compared to $\mathrm{OH}$. The reactor is operated at higher pressure $(25 \mathrm{hPa})$ compared to the low-pressure $(4 \mathrm{hPa}) \mathrm{LIF}$ detection cell (Fuchs et al., 2009). The $\mathrm{HO}_{x}$ is sampled from the reactor into the LIF detection cell where $\mathrm{HO}_{2}$ is converted by a large excess of added NO to $\mathrm{OH}$. Operational parameters of the $\mathrm{RO}_{2}$ system are optimized for the efficient detection of $\mathrm{RO}_{2}$ radicals that have a similar reaction rate with $\mathrm{NO}$ as methylperoxy radicals. As a consequence, $\mathrm{RO}_{2}$ radicals are not efficiently detected, if their reaction with NO does not directly and quantitatively result in the production of $\mathrm{HO}_{2}$. This is for example the case for the peroxy radical $\mathrm{HMVKBO}_{2}$ (as named in the MCM) that is formed from the reaction of $\mathrm{MVK}$ with $\mathrm{OH}$ (see below for details). This has 


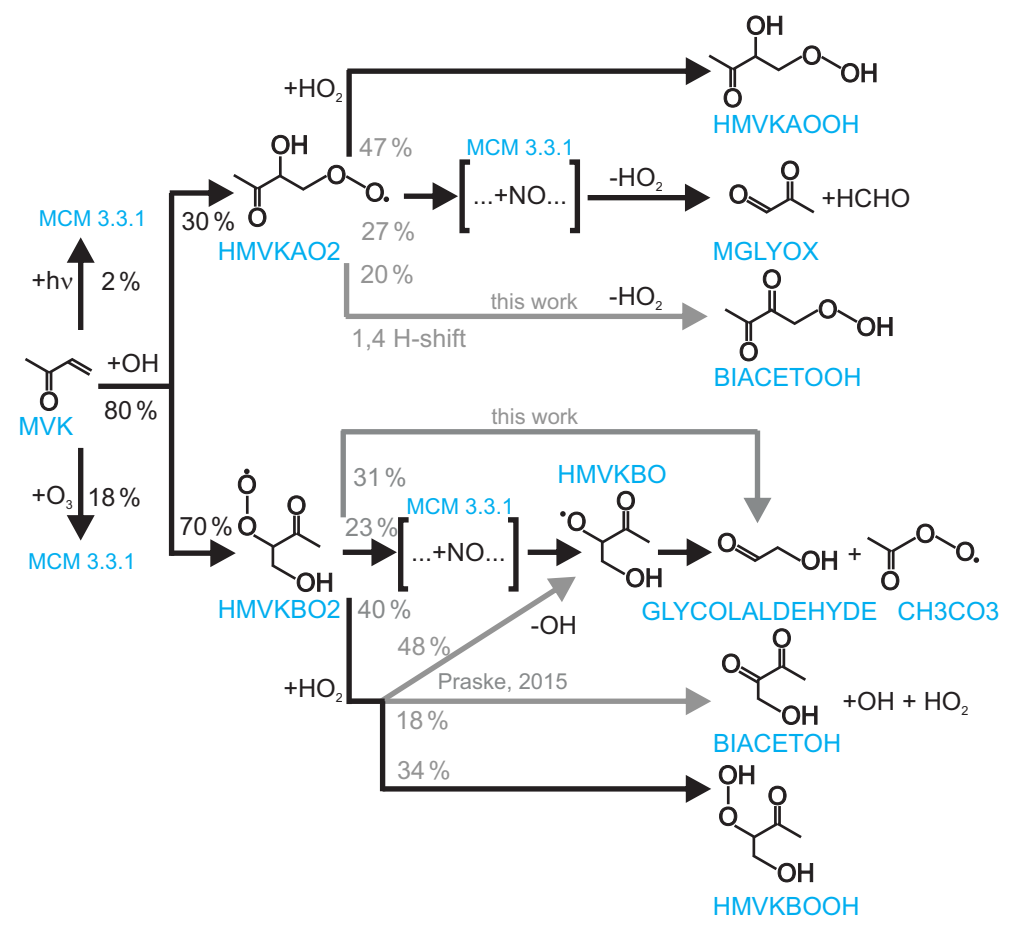

Figure 1. Simplified $\mathrm{OH}$ oxidation scheme for MVK. Names of compounds are assigned similar to MCM. Modifications to the MCM mechanism (M2) applied in model sensitivity runs M1 and M2 (Table 1) are shown as grey arrows. Reaction yields are calculated for conditions of the experiment with low NO (high ozone concentrations) on 23 May 2017. Grey numbers refer to model run M2.

to be taken into account, if measured $\mathrm{RO}_{2}$ radicals are compared with model calculations.

The $\mathrm{HO}_{2}$ detection cell consists of a fluorescence cell, in which $\mathrm{HO}_{2}$ reacts with excess $\mathrm{NO}$ that is injected behind the inlet nozzle. As shown for several LIF instruments, the $\mathrm{HO}_{2}$ signal can also contain contributions from $\mathrm{RO}_{2}$ radicals that rapidly form $\mathrm{HO}_{2}$ in the reaction with $\mathrm{NO}$ (Fuchs et al., 2011; Whalley et al., 2013; Lew et al., 2018). This applies for those $\mathrm{RO}_{2}$ radicals which form an alkoxy radical (RO) in the reaction with $\mathrm{NO}$ that rapidly produces $\mathrm{HO}_{2}$ and other products. The interferences from $\mathrm{RO}_{2}$ can be minimised; however, if the instrument is operated with an NO concentration, for which the $\mathrm{HO}_{2}$ to $\mathrm{OH}$ conversion efficiency is only approximately less than $10 \%$. In this case, the $\mathrm{RO}_{2}$ to $\mathrm{OH}$ conversion efficiency becomes much smaller for all $\mathrm{RO}_{2}$ species, because the two reactions with $\mathrm{NO}$ needed to produce $\mathrm{OH}$ limit the overall conversion efficiency. In this study, the $\mathrm{HO}_{2}$ channel of the LIF instrument was operated such that $\mathrm{RO}_{2}$ interferences can be assumed to be negligible.

In one of the experiments (23 May 2017), $\mathrm{HO}_{2}$ was additionally detected by a newly developed chemical ionisation mass spectrometry (CIMS) instrument using $\mathrm{Br}^{-}$as ionisation reagent. $\mathrm{HO}_{2}$ is detected as cluster ion similar to the approaches reported by Veres et al. (2015); Sanchez et al. (2016) using an $\mathrm{I}^{-}$and $\mathrm{Br}^{-}$CIMS, respectively. Details of this new instrument will be presented in a separate publica- tion. $\mathrm{HO}_{2}$ measurements of the CIMS instrument agreed with $\left[\mathrm{HO}_{2}\right]$ detected by the LIF instrument within $15 \%$.

Solar radiation was measured outside the chamber using a spectroradiometer. Photolysis frequencies are then calculated by applying a model to transfer outside conditions to conditions inside the chamber (Bohn et al., 2005; Bohn and Zilken, 2005). Latest recommendations for absorption spectra and photolysis yields are used.

\subsection{Model calculations}

Model calculations were performed using the Master Chemical Mechanism in its latest version 3.3.1 (MCM, 2017). A simplified reaction scheme is shown in Fig. 1. The MCM mechanism was modified $\left(\mathrm{MCM}^{*}\right)$ to take results reported in literature into account and findings in this work. Details are listed in Table 1.

Chamber specific properties were added such as dilution of traces gases due to the replenishment flow. Sources for $\mathrm{HONO}$ and $\mathrm{HCHO}$ production from the chamber were parameterised as described in previous publications (e.g. Fuchs et al., 2014; Kaminski et al., 2017).

Model calculations were constrained to physical parameters (pressure, temperature, photolysis frequencies and dilution rate of trace gases). A small, constant background $\mathrm{OH}$ reactivity of unknown $\mathrm{OH}$ reactants that was measured by the $\mathrm{OH}$ reactivity instrument after humidification of the chamber 
Table 1. Changes of reactions and additional reactions applied to the MCM.

\begin{tabular}{|c|c|c|c|}
\hline & Reaction & Reaction rate constant & Reference \\
\hline & \multicolumn{3}{|l|}{$\mathrm{MCM}^{*}:$} \\
\hline R1: & $\mathrm{OH}+\mathrm{MVK} \rightarrow \mathrm{HMVKAO}_{2}$ & $0.24 \times 2.6 \times 10^{-12} \exp \left(610 \mathrm{~K} \mathrm{~T}^{-1}\right) \mathrm{cm}^{3} \mathrm{~s}^{-1}$ & Praske et al. (2015) \\
\hline \multirow[t]{4}{*}{ R2: } & $\mathrm{OH}+\mathrm{MVK} \rightarrow \mathrm{HMVKBO}_{2}$ & $0.76 \times 2.6 \times 10^{-12} \exp \left(610 \mathrm{~K} \mathrm{~T}^{-1}\right) \mathrm{cm}^{3} \mathrm{~s}^{-1}$ & Praske et al. (2015) \\
\hline & $\mathrm{HOCH}_{2} \mathrm{CHO}+\mathrm{OH} \rightarrow$ products & $8 \times 10^{-12} \mathrm{~cm}^{3} \mathrm{~s}^{-1}$ & Karunanandan et al. (2007) \\
\hline & $\mathrm{MVK}+\mathrm{O}_{3} \rightarrow \mathrm{OH}+$ products & $0.16 \times 8.5 \times 10^{-16} \exp \left(-1520 \mathrm{~K} \mathrm{~T}^{-1}\right)$ & $\begin{array}{l}\text { Aschmann et al. (1996), } \\
\text { Paulson et al. (1998) }\end{array}$ \\
\hline & \multicolumn{3}{|l|}{ M1 (includes $\mathrm{MCM}^{*}$ ): } \\
\hline R3: & $\mathrm{HMVKBO}_{2}+\mathrm{HO}_{2} \rightarrow \mathrm{HMVKBOOH}$ & $0.34 \times 0.625 \mathrm{KRO}_{2} \mathrm{HO}^{\mathrm{a}}$ & Praske et al. (2015) \\
\hline R4: & $\mathrm{HMVKBO}_{2}+\mathrm{HO}_{2} \rightarrow \mathrm{HMVKBO}+\mathrm{OH}$ & $0.48 \times 0.625 \mathrm{KRO}_{2} \mathrm{HO}^{\mathrm{a}}$ & Praske et al. (2015) \\
\hline \multirow[t]{2}{*}{ R5: } & $\mathrm{HMVKBO}_{2}+\mathrm{HO}_{2} \rightarrow \mathrm{BIACETOH}+\mathrm{OH}+\mathrm{HO}_{2}$ & $0.18 \times 0.625 \mathrm{KRO}_{2} \mathrm{HO}^{\mathrm{a}}$ & Praske et al. (2015) \\
\hline & \multicolumn{3}{|l|}{ M2 (includes M1 and $\mathrm{MCM}^{*}$ ): } \\
\hline R7: & $\mathrm{HMVKAO}_{2} \rightarrow \mathrm{HO}_{2}+\mathrm{BIACETOOH}$ & $0.003 \mathrm{~s}^{-1 \mathrm{~b}}$ & This work \\
\hline \multirow[t]{2}{*}{ R8: } & $\begin{array}{l}\mathrm{HMVKBO}_{2}(+\mathrm{X})^{\mathrm{c}} \rightarrow \mathrm{HO}_{2}+\mathrm{HOCH}_{2} \mathrm{CHO} \\
+\mathrm{HCHO}+\mathrm{CO}\end{array}$ & $(0.006 \pm 0.004) \mathrm{s}^{-1}$ & This work \\
\hline & $\mathrm{HOCH}_{2} \mathrm{CO}_{3}+\mathrm{NO}_{2} \rightarrow \mathrm{PHAN}$ & 0 & This work \\
\hline
\end{tabular}

${ }^{a}$ value from MCM: $0.625 \mathrm{KRO} 2 \mathrm{HO} 2=2.91 \times 10^{-13} \exp \left(1300 \mathrm{~K} \mathrm{~T}^{-1}\right) \mathrm{cm}^{3} \mathrm{~s}^{-1}(\mathrm{MCM}, 2017){ }^{\mathrm{b}}$ from theoretical calculation (see Table 2). ${ }^{\mathrm{c}}$ A reaction partner could not be determined from these experiments.

air was modelled as an $\mathrm{OH}$ reactant that converts $\mathrm{OH}$ to $\mathrm{HO}_{2}$. However, the magnitude of this background reactivity was small $\left(<1 \mathrm{~s}^{-1}\right)$ compared to the $\mathrm{OH}$ reactivity from MVK during the experiment $\left(>15 \mathrm{~s}^{-1}\right)$ so that it did not affect the chemistry.

Injections of trace gases were modelled as sources during the time of injection, but injected trace gases were not constrained to measured values at later times. [NO], $\left[\mathrm{NO}_{2}\right]$ and $\left[\mathrm{O}_{3}\right]$ were only constrained to measurements for the high $\mathrm{NO}_{x}$ experiment, because differences between modelled and measured values would have led to significant differences in other observables. No modelling could be performed for one of the high NO experiments (17 May 2017) due to the lack of $\mathrm{NO}_{x}$ measurements. No measurements for the reaction rate constants of $\mathrm{RO}_{2}$ species from MVK exist. The sensitivity of model results to a change of the $\mathrm{RO}_{2}$ reaction rate constants, however, is rather small so that their uncertainties could not explain observed model-measurements discrepancies.

\subsection{Quantum-chemical calculations}

A set of H-migration reactions for the main MVK-derived peroxy radicals was investigated by quantum chemical and theoretical kinetic methodologies. The reactions studied included migration of hydroxyl, $\alpha-\mathrm{OH}$, and methyl $\mathrm{H}$-atoms; direct $\mathrm{HO}_{2}$ elimination forming an enol was also investigated (Table 2).

Several methodologies were applied, as detailed in the supporting information. From these data, the M06-2X/ccpVTZ rovibrational data (Dunning, 1989; Zhao and Truhlar, 2008), with CCSD(T)/aug-schwartz4(DT) single point energy calculations extrapolated to the basis set limit (Purvis and Bartlett, 1982; Martin, 1996) were selected. All quantum chemical calculations were performed using the Gaussian-09 program suite (Frisch et al., 2010). The high-pressure rate coefficients for each of the elementary processes was then calculated using multi-conformer canonical transition state theory, MC-CTST (Vereecken and Peeters, 2003; Zheng and Truhlar, 2013) based on a rigid rotor harmonic oscillator paradigm, an exhaustive search of the reactants and TS conformers, and asymmetric Eckart tunnelling and WKB zerocurvature (ZCT) tunnelling. For the 1,4- and 1,6-H-shift in $\mathrm{HMVKAO}_{2}$, a large difference between Eckart and ZCT tunnelling was found; the geometric average is reported here (see Supplement).

\section{Results}

\subsection{Product yields}

The reaction of $\mathrm{OH}$ with $\mathrm{MVK}$ leads to the addition of $\mathrm{OH}$ to either one of the double-bonded C-atoms so that two different $\mathrm{RO}_{2}$ radical species can be formed (Fig. 1):

$\mathrm{MVK}+\mathrm{OH} \rightarrow \mathrm{HMVKAO}_{2}$ (yield : 0.3),

$\mathrm{MVK}+\mathrm{OH} \rightarrow \mathrm{HMVKBO}_{2}$ (yield : 0.7)

Yields are from current recommendations (Atkinson et al., 2006) that are also used in the MCM. The further reaction chain with NO gives glycolaldehyde and an acetylperoxy radical for $\mathrm{HMVKBO}_{2}$ and methylglyoxal, formaldehyde and $\mathrm{HO}_{2}$ for $\mathrm{HMVKAO}_{2}$. In the low $\mathrm{NO}$ experiment 
Table 2. H-migration and $\mathrm{HO}_{2}$ elimination in hydroxy-MVK-peroxy radicals. Barrier height $E_{\mathrm{b}}$, reaction energy $E_{\text {react }}$ and the rate coefficient $k$ at a temperature of $300 \mathrm{~K}$ are listed. Arrhenius expressions for a temperature range between 200 and $400 \mathrm{~K}$ are available in the Supplement.

\begin{tabular}{|c|c|c|c|c|c|}
\hline Reactant & Reaction class & Product & $\begin{array}{r}E_{\mathrm{b}} \\
\mathrm{kcal} \mathrm{mol}^{-1}\end{array}$ & $\begin{array}{r}E_{\text {react }} \\
\text { kcal mol }\end{array}$ & $\begin{array}{l}k(300 \mathrm{~K}) \\
\mathrm{s}^{-1}\end{array}$ \\
\hline \multirow[t]{3}{*}{$\mathrm{HMVKAO}_{2}$} & -OH 1,5-H-shift & $\mathrm{CH}_{3}-\mathrm{C}(=\mathrm{O})-\mathrm{CH}\left(\mathrm{O}^{\bullet}\right)-\mathrm{CH}_{2} \mathrm{OOH}$ & 21.6 & 20.4 & $5.0 \times 10^{-4}$ \\
\hline & $\alpha-\mathrm{OH} 1,4-\mathrm{H}-\mathrm{shift}$ & $\mathrm{CH}_{3}-\mathrm{C}(=\mathrm{O})-\mathrm{C}^{\bullet}(\mathrm{OH})-\mathrm{CH}_{2} \mathrm{OOH}$ & 24.7 & -6.2 & $3.3 \times 10^{-3}$ \\
\hline & $-\mathrm{CH}_{3}$ 1,6-H-shift & $\mathrm{C}^{\bullet} \mathrm{H}_{2}-\mathrm{C}(=\mathrm{O})-\mathrm{CH}(\mathrm{OH})-\mathrm{CH}_{2} \mathrm{OOH}$ & 23.1 & 10.2 & $5.9 \times 10^{-4}$ \\
\hline \multirow[t]{4}{*}{$\mathrm{HMVKBO}_{2}$} & $-\mathrm{OH}$ 1,5-H-shift & $\mathrm{CH}_{3}-\mathrm{C}(=\mathrm{O})-\mathrm{CH}(\mathrm{OOH})-\mathrm{CH}_{2} \mathrm{O}^{\bullet}$ & 22.5 & 20.6 & $8.8 \times 10^{-5} \mathrm{a}$ \\
\hline & $\alpha-\mathrm{OH} 1,4-\mathrm{H}-\mathrm{shift}$ & $\mathrm{CH}_{3}-\mathrm{C}(=\mathrm{O})-\mathrm{CH}(\mathrm{OOH})-\mathrm{C}^{\bullet} \mathrm{HOH}$ & 25.1 & 6.5 & $3.2 \times 10^{-5}$ \\
\hline & $-\mathrm{CH}_{3}$ 1,6-H-shift & $\mathrm{C}^{\bullet} \mathrm{H}_{2}-\mathrm{C}(=\mathrm{O})-\mathrm{CH}(\mathrm{OOH})-\mathrm{CH}_{2} \mathrm{OH}$ & 27.4 & 10.0 & $3.8 \times 10^{-5}$ \\
\hline & $\mathrm{HO}_{2}$ elimination & $\mathrm{CH}_{3}-\mathrm{C}(=\mathrm{O})-\mathrm{CH}=\mathrm{CHOH}+\mathrm{HO}_{2}$ & 30.0 & -1.5 & $6.1 \times 10^{-10}$ \\
\hline
\end{tabular}

a estimated at $0.01 \mathrm{~s}^{-1}$ by Peeters et al. (2009).
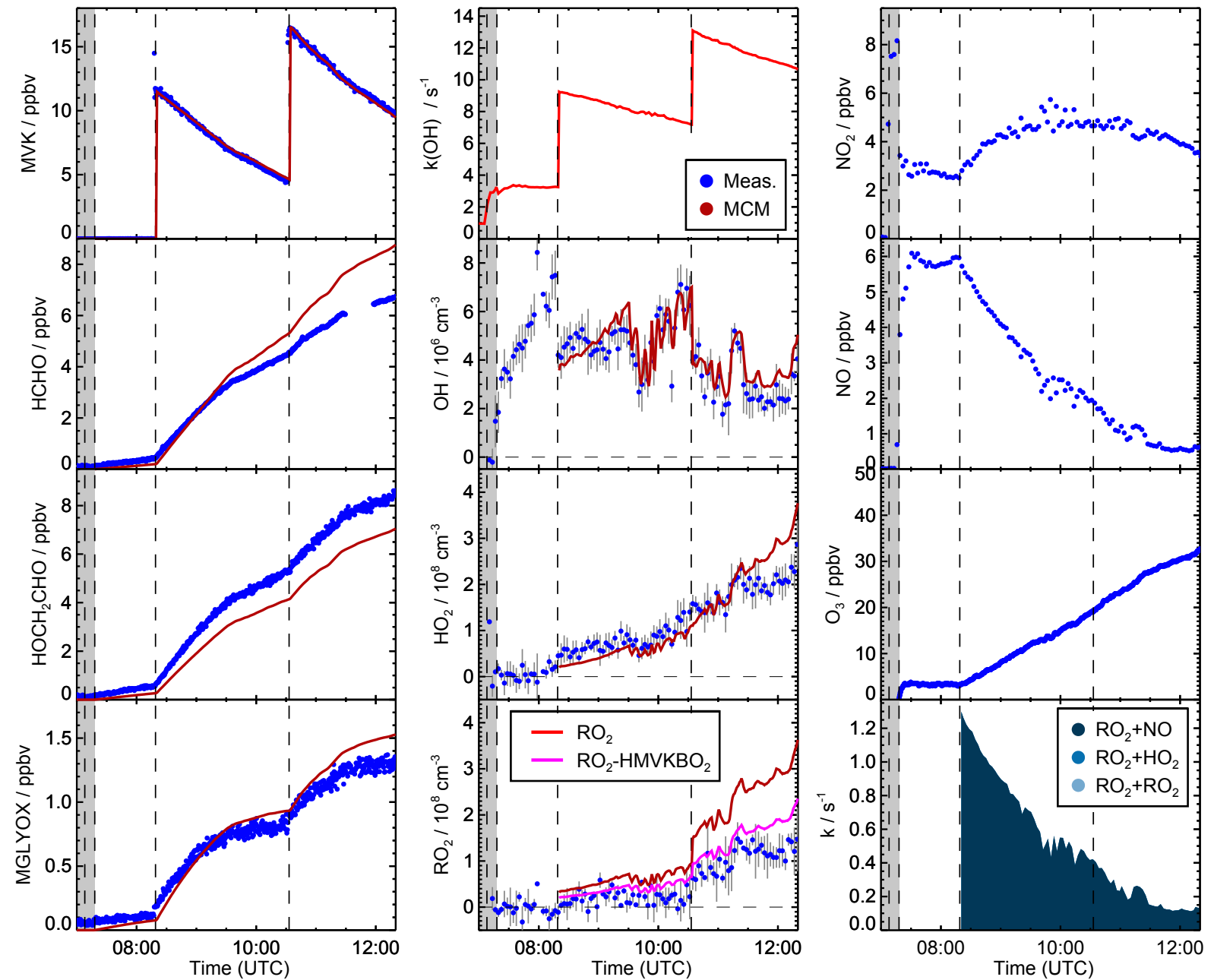

Figure 2. Time series of radicals, inorganic and organic species during the MVK photooxidation for the high NO experiment (20 August 2014) together with results from model calculations applying MCM. Dark shaded areas indicate the time before opening the chamber roof and vertical dashed line times when trace gases were injected into the chamber. $\mathrm{OH}$ reactivity was not measured during this experiment. $\mathrm{NO}, \mathrm{NO}_{2}$ and $\mathrm{O}_{3}$ are constrained to measurements in the model. $\mathrm{RO}_{2}$ loss rates (most lowest right panel) are calculated from modelled $\mathrm{HO}_{2}$, $\mathrm{RO}_{2}$ and $\mathrm{NO}$ concentrations. However, contributions from the reactions with $\mathrm{RO}_{2}$ and $\mathrm{HO}_{2}$ or $\mathrm{RO}_{2}$ are too small to be visible. Modelled acetic acid concentrations are small compared to modelled glycolaldehyde concentrations (measured together in the PTR-TOF-MS). 

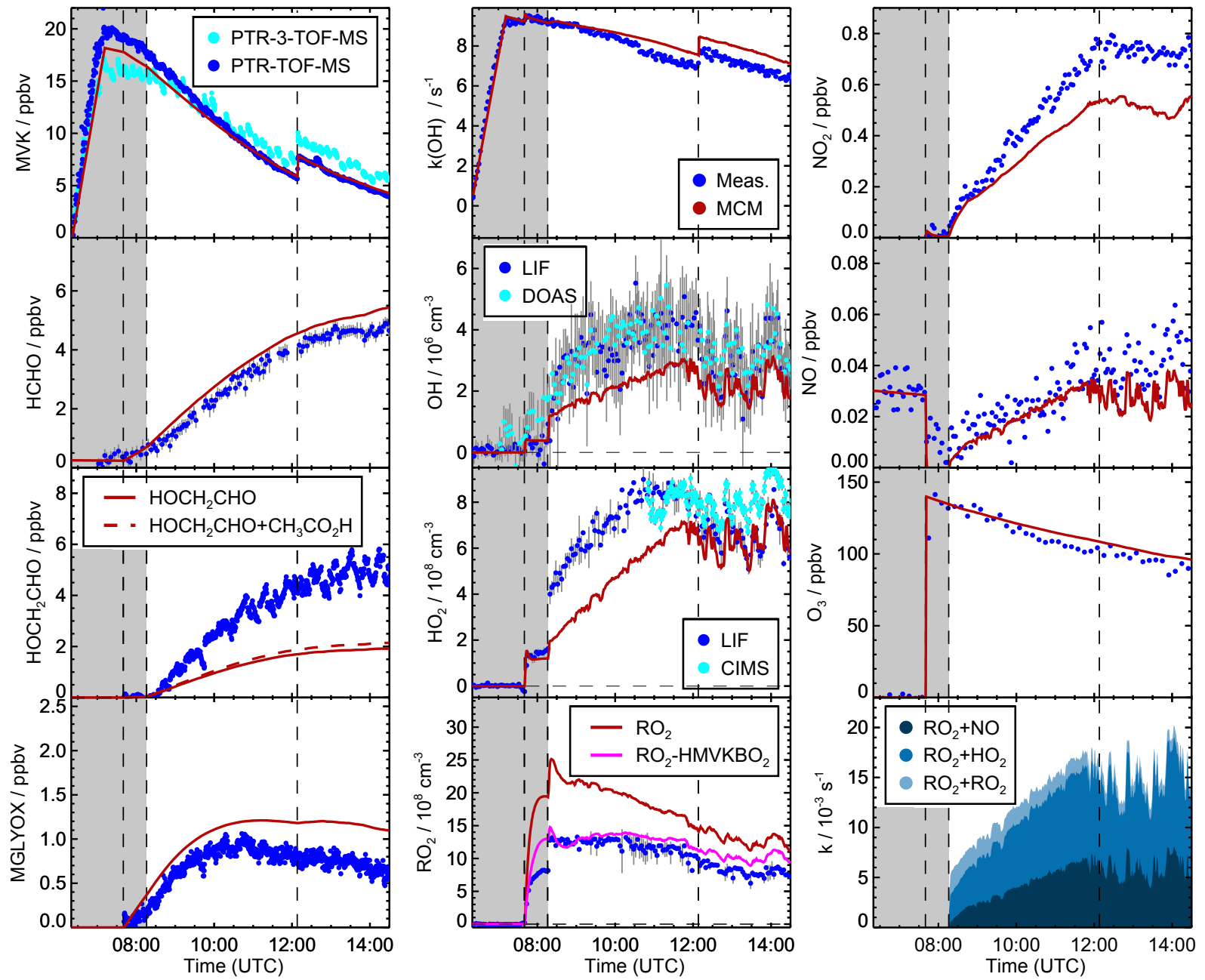

Figure 3. Time series of radicals, inorganic and organic species during the MVK photooxidation at low NO (23 May 2017) together with results from model calculations applying MCM. Dark shaded areas indicate the time before opening the chamber roof and vertical dashed line times when trace gases were injected into the chamber. $\mathrm{RO}_{2}$ loss rates (most lowest right panel) are calculated from modelled $\mathrm{HO}_{2}$, $\mathrm{RO}_{2}$ and NO concentrations.

(23 May 2017), approximately $30 \%$ of the $\mathrm{RO}_{2}$ reacted with $\mathrm{NO}$ assuming that the reaction with $\mathrm{HO}_{2}$ was the only competing reaction. In contrast, more than $90 \%$ of $\mathrm{RO}_{2}$ reacted with NO in the high NO experiment. Mixing ratios of the major products formaldehyde, glycolaldeyde and methylglyoxal increased to 6,8 , and $1.3 \mathrm{ppbv}$, respectively, in the high NO experiment when 13 ppbv MVK was oxidised (Fig. 2). Less of these products was observed in the low NO experiment with $4.5 \mathrm{ppbv}$ formaldehyde, $5 \mathrm{ppbv}$ glycolaldehyde and $1 \mathrm{ppbv}$ methylglyoxal (Fig. 3) when $17 \mathrm{ppbv}$ MVK is oxidised. The smaller concentrations of these products in the low NO case might be expected, because other products can be formed in the competing $\mathrm{RO}_{2}$ reaction channels (Fig. 1).

Because part of the products are oxidised during the experiment, a correction procedure described in detail by Galloway et al. (2011) and Kaminski et al. (2017) is applied, in order to calculate products yields originating from the oxi- dation of MVK. This correction takes loss of products due to the reaction with $\mathrm{OH}$ and photolysis into account and also small production from chamber sources. The relationship between consumed MVK and corrected product concentrations gives the yield of the product species (Table 3, Fig. S3).

For the high $\mathrm{NO}$ experiment, when $\mathrm{RO}_{2}$ nearly exclusively reacted with NO, the ratio of product yields for glycolaldehyde $(0.65 \pm 0.14)$ and methylglyoxal $(0.19 \pm 0.03)$ can be related to the branching ratio of the MVK reaction with $\mathrm{OH}$ (Reactions R1 and R2), because these products are formed in either one of the two reaction channels. The values derived from this experiment agree within their uncertainties with studies by Galloway et al. (2011), Tuazon and Atkinson (1989), and Praske et al. (2015) all reporting lower methylglyoxal yields than suggested by current recommendations (Atkinson et al., 2006). This indicates that the branching ratio assumed in the MCM of $0.7: 0.3$ needs to be shifted to- 
Table 3. Yields of organic products from photooxidation of MVK by OH from this work and from the literature. Errors of values from this work take into account the accuracy of measurements and precision of the calculation. HCHO is not only produced in the first oxidation step of MVK but also produced in the subsequent oxidation of glycolaldehyde and methylglyoxal. Therefore, the yield can increase over the course of the experiment.

\begin{tabular}{llcl}
\hline Species & Yield & $\frac{\operatorname{loss}\left(\mathrm{RO}_{2}+\mathrm{HO}_{2}\right)}{\operatorname{loss}\left(\mathrm{RO}_{2}+\mathrm{NO}\right)}$ & Reference \\
\hline \multirow{3}{*}{ HCHO } & $0.24 \pm 0.08^{\mathrm{a}}$ & $2: 1^{\mathrm{c}}$ & This work \\
& $0.46 \pm 0.04^{\mathrm{b}}$ & $2: 1^{\mathrm{c}}$ & This work \\
& $0.73 \pm 0.15$ & $1: 9$ & This work \\
& $0.54 \pm 0.04$ & $0: 1$ & Tuazon and Atkinson (1989) \\
& $0.05 \pm 0.02$ & $2: 1^{\mathrm{c}}$ & This work \\
MGLYOX & $0.04 \pm 0.01$ & $1: 0$ & Praske et al. (2015) \\
& $0.19 \pm 0.03$ & $1: 9$ & This work \\
& $0.24 \pm 0.001$ & $0: 1$ & Galloway et al. (2011) \\
& $0.25 \pm 0.08$ & $0: 1$ & Tuazon and Atkinson (1989) \\
& 0.32 & $0: 1$ & Grosjean et al. (1993) \\
& $0.38 \pm 0.05$ & $1: 0$ & Praske et al. (2015) \\
& $0.65 \pm 0.14$ & $1: 9$ & this work \\
& $0.74 \pm 0.06$ & $0: 1$ & Praske et al. (2015) \\
& $0.67 \pm 0.04$ & $0: 1$ & Galloway et al. (2011) \\
HOCH $_{2} \mathrm{CHO}$ & $0: 1$ & Tuazon and Atkinson (1989) \\
& $0.64 \pm 0.16$ & $0: 1$ & Grosjean et al. (1993) \\
& 0.60 & $2: 1^{\mathrm{c}}$ & This work \\
& & 0.09 &
\end{tabular}

${ }^{\mathrm{a}}$ approximately after $1 \mathrm{~h}$ of oxidation. ${ }^{\mathrm{b}}$ after $3 \mathrm{~h}$ of oxidation. ${ }^{\mathrm{c}} \mathrm{RO}_{2}+\mathrm{RO}_{2}$ contribution to the total $\mathrm{RO}_{2}$ loss: $<20 \%$.

wards $\mathrm{HMVKBO}_{2}$. Praske et al. (2015) suggests a branching ratio of $0.76: 0.24$. The formaldehyde yield of $0.73 \pm 0.15$ is higher than the methylglyoxal yield, because formaldehyde is not only a co-product of methylglyoxal in the reaction chain of $\mathrm{HMVKAO}_{2}$ (Fig. 1), but can also be formed from secondary products in the oxidation scheme of MVK. This might also explain why the HCHO yield in this chamber experiment is higher than that in the study by Tuazon and Atkinson (1989). Product yields reported by Grosjean et al. (1993) differ for all three species (largest difference for formaldehyde) from the other studies for unclear reasons.

In the low NO case, other $\mathrm{RO}_{2}$ reaction channels than reaction with NO gain in importance. Lower yields of methylglyoxal $(0.05 \pm 0.002)$ and glycolaldehyde $(0.37 \pm 0.09)$ compared to the high NO experiment are therefore found in this case. However, the relative decrease of glycolaldehyde is much smaller than that of methylglyoxal. This indicates that glycolaldehyde is also formed from other reaction channels than the reaction of $\mathrm{HMVKBO}_{2}$ with NO. This agrees with results reported by Praske et al. (2015). In that study, a glycolaldehyde yield of $0.38 \pm 0.05$ was determined in experiments, in which $\mathrm{RO}_{2}$ exclusively reacted with $\mathrm{HO}_{2}$.

\subsection{Modelled and measured time series of radical concentrations}

Time series of trace gas and radical concentrations are shown together with model calculations using the MCM without modifications for one of the high NO experiments (Fig. 2, 20 August 2014) and for one of the low NO experiments (Fig. 3, 23 May 2017). Although the instrumentation that performed measurements in the experiments were partly different specifically for experiments done in different years, consistent results are obtained. In addition, parameters that are measured by two instruments agree within their combined uncertainties.

MVK (12 ppbv) was injected twice into the sunlit chamber in the high NO experiment (Fig. 2). Approximately half of the MVK reacted away before the second MVK addition was done. The NO mixing ratio decreased over the course of the experiment from nearly 6 to $0.5 \mathrm{ppbv}$, but was sufficiently high that $90 \%$ of $\mathrm{HO}_{2}$ reacted with $\mathrm{NO}$ for most of the time. $\mathrm{OH}$ concentrations ranged from $(2-4) \times 10^{6} \mathrm{~cm}^{-3}$ modulated by changes of the $\mathrm{OH}$ reactivity and radiation. Model calculations of $[\mathrm{OH}]$ agree with measurements within $20 \%$ at all times during the oxidation of MVK. This corresponds to a good description of the measured MVK concentration by the model (deviations less than 5\%) demonstrating that the $\mathrm{OH}$ concentration fits the observed oxidation rate of MVK. 
$\mathrm{HO}_{2}$ and $\mathrm{RO}_{2}$ radical concentrations were rather small $\left(<2 \times 10^{8} \mathrm{~cm}^{-3}\right)$ due to their fast loss in the presence of high NO. Measured and modelled $\mathrm{HO}_{2}$ concentrations show good agreement until the NO mixing ratio decreased below $0.5 \mathrm{ppbv}$ (at 11:00, Fig 2). In the case of $\mathrm{RO}_{2}$, the model yields significantly larger concentrations than measurements. This discrepancy is plausible due to the incomplete conversion of the peroxy radical $\mathrm{HMVKBO}_{2}$ in the prereactor. The transformation to $\mathrm{HO}_{2}$ requires more than one NO reaction step and therefore remains incomplete during the transit through the reactor. If the modelled concentration of $\left[\mathrm{HMVKBO}{ }_{2}\right]$ is subtracted from the total modelled $\left[\mathrm{RO}_{2}\right]$, good model-measurement agreement is obtained.

Overall, the good agreement between modelled and measured radical concentrations demonstrates that radical chemistry during the oxidation of MVK is well described by stateof-the-art chemical models, if $\mathrm{RO}_{2}$ radicals are mainly lost in the reaction with NO.

In the low NO experiment (Fig. 3), approximately $20 \mathrm{ppbv}$ of MVK was injected, before photooxidation started. As a consequence of the low $\mathrm{NO}(<40 \mathrm{pptv}), \mathrm{RO}_{2}$ radicals formed in the reaction of MVK with $\mathrm{OH}$ not only reacted with $\mathrm{NO}$, but reaction with $\mathrm{HO}_{2}$ and $\mathrm{RO}_{2}$ were competitive. Model calculations using the MCM (Fig. 3) suggest that at least half of the $\mathrm{RO}_{2}$ reacted with $\mathrm{HO}_{2}$ and a smaller fraction (10 to $20 \%$ ) with other $\mathrm{RO}_{2}$ radicals.

After nearly $6 \mathrm{~h}$ of oxidation, only $4 \mathrm{ppbv}$ MVK was left in the presence of $(2-4) \times 10^{6} \mathrm{~cm}^{-3} \mathrm{OH}$. The amount of MVK that is injected in the model is adjusted to the increase in $\mathrm{OH}$ reactivity during the time of injection. The $10 \%$ discrepancy to measured MVK mixing ratios is within the uncertainty of the PTR-TOF-MS calibration. However, the decay of the measured [MVK] is slightly faster than the decay in the model specifically during the first $2 \mathrm{~h}$ of oxidation. This corresponds to modelled $\mathrm{OH}$ concentrations, which are up to a factor of 2 smaller than measured $\mathrm{OH}$ concentrations during this time. At later times of the experiment, measured and modelled $[\mathrm{OH}]$ as well as the relative change in $[\mathrm{MVK}]$ are matched. Differences between measured and modelled $\mathrm{OH}$ concentrations in the first phase of the experiment are accompanied by $\mathrm{HO}_{2}$ concentrations, which are approximately $2 \times 10^{8} \mathrm{~cm}^{-3}$ lower in the model compared to measured values. Measured $\left[\mathrm{HO}_{2}\right]$ increased from $(4-8) \times 10^{8} \mathrm{~cm}^{-3}$ during the first $2 \mathrm{~h}$. Modelled values match measurements at later times of the experiment like observed for $[\mathrm{OH}]$. The concurrent underestimation of $[\mathrm{OH}]$ and $\left[\mathrm{HO}_{2}\right]$ suggests that a radical source is missing in the model.

In a sensitivity run $\left(\mathrm{MCM}^{*}\right)$, modifications of reactions that are reported in literature, but do not directly affect the fate of $\mathrm{RO}_{2}$ are implemented:

- The reaction rate constant of glycolaldehyde with $\mathrm{OH}$ is lowered by $20 \%$ following measurements by Karunanandan et al. (2007).
- Following the results of the product analysis (see above), the branching ratio of Reaction (R1) and R2 is changed from $0.3: 0.7$ to $0.24: 0.76$ as suggested by Praske et al. (2015).

- OH yield from ozonolysis of MVK is lowered to $16 \%$ as determined by Aschmann et al. (1996) and Paulson et al. (1998) compared to $36 \%$ assumed in the MCM.

Details are listed in Table 1. Differences with results with the current version of the MCM are rather small (not shown here) so that these modifications do not significantly affect the model-measurement agreement. They are included in the sensitivities model runs shown below.

\section{Discussion}

\subsection{Additional $\mathrm{RO}_{2}+\mathrm{HO}_{2}$ reactions}

Product yields indicate that an additional source for glycolaldehyde that is not included in the MCM is required to explain observations in the low NO experiment. This is consistent with chamber experiments by Praske et al. (2015), which were performed under conditions that $\mathrm{RO}_{2}$ exclusively reacted with $\mathrm{HO}_{2}$. In this case, the glycolaldehyde yield is expected to be small, because glycolaldehyde is mainly formed in the subsequent reaction of $\mathrm{RO}_{2}$ with $\mathrm{NO}$ (Fig. 1). In that study, also a $\mathrm{C}_{4} \alpha$-diketone $\left(\mathrm{CH}_{3} \mathrm{COCOCH}_{2} \mathrm{OH}, \mathrm{MCM}\right.$ name: BIACETOH) was measured with a yield of 0.14. From these product yields, the authors suggest that there are reaction channels of the $\mathrm{HMVKBO}_{2}$ plus $\mathrm{HO}_{2}$ reaction in addition to the formation of hydroxyperoxides (Praske et al., 2015):

$$
\begin{array}{cc}
\mathrm{HMVKBO}_{2}+\mathrm{HO}_{2} \rightarrow & \mathrm{HMVKBOOH} \\
& (\text { yield : } 0.34), \\
\mathrm{HMVKBO}_{2}+\mathrm{HO}_{2} \rightarrow & \mathrm{H} \\
& (\text { yield : } 0.48), \\
\mathrm{HMVKBO}_{2}+\mathrm{HO}_{2} \rightarrow & \text { BIACETOH }+\mathrm{OH}+\mathrm{HO}_{2} \\
& (\text { yield : } 0.18),
\end{array}
$$

Including Reactions (R3)-(R5) in the MCM* mechanism (M1 Table 1) results in an improved description of observations for the low NO experiment (Fig. 4). Modelled [OH] agrees with measurements within $20 \%$. The largest increase of modelled $[\mathrm{OH}]$ is obtained 1 to $2 \mathrm{~h}$ after starting the oxidation due to the additional radical regeneration from Reactions (R4) and (R5). The model-measurement agreement is worsened for $\left[\mathrm{RO}_{2}\right]$ compared to the MCM model run, but still within the uncertainty of the measurement. The additional production of glycolaldehyde from the subsequent chemistry of Reaction (R4) brings modelled organic product species into agreement with measurements within $20 \%$ so that all observations except for $\left[\mathrm{HO}_{2}\right]$ can be explained by the new reactions of $\mathrm{HMVKBO}_{2}$ with $\mathrm{HO}_{2} \cdot \mathrm{HO}_{2}$ concentrations, 

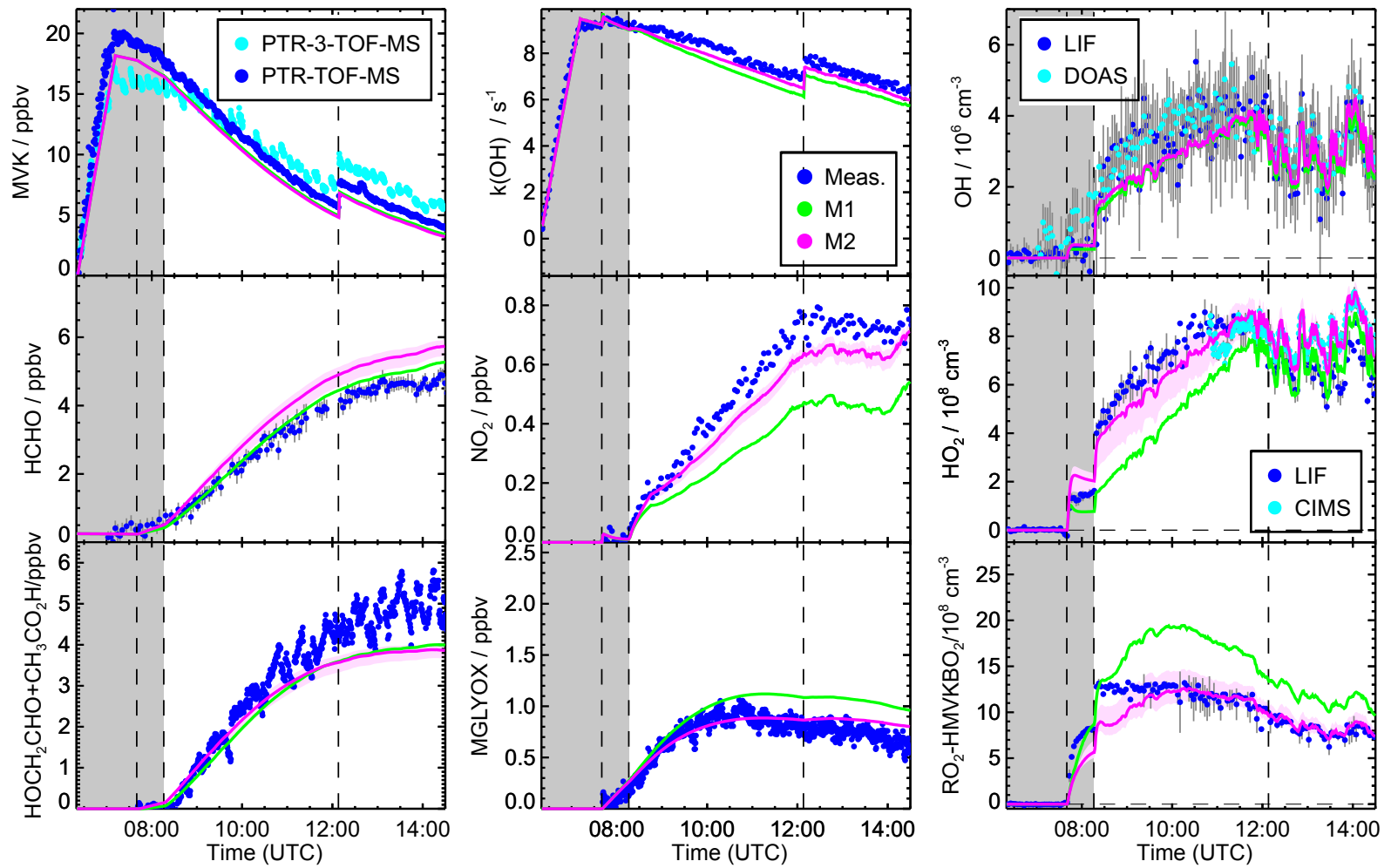

Figure 4. Time series of radicals, inorganic and organic species during the MVK photooxidation at low NO (experiment on 23 May 2017 ). Dark shaded areas indicate the time before opening the chamber roof and vertical dashed line times when trace gases were injected into the chamber. Model sensitivity runs M1 and M2 include modifications listed in Table 1.

however, are still significantly lower in the model compared to measurements. Results are consistent with experiments by Praske et al. (2015), but a potential underestimation of $\left[\mathrm{HO}_{2}\right]$ could not be recognised, because $\mathrm{HO}_{2}$ radicals were not measured in their experiments.

\section{2 $\mathrm{RO}_{2}$ isomerisation reactions}

$\mathrm{RO}_{2}$ isomerisation reactions have been shown to be of importance for the atmospheric fate of $\mathrm{RO}_{2}$ from isoprene (Peeters et al., 2014). Peeters et al. (2009) also suggested from quantum-chemical calculations that $\mathrm{HMVKBO}_{2}$ undergoes a fast 1,5-H shift with subsequent decomposition (Fig. 1 and Table 1):

$\mathrm{HMVKBO}_{2} \rightarrow \mathrm{MGLYOX}+\mathrm{HCHO}+\mathrm{OH}$.

Here, the possibility of $\mathrm{RO}_{2}$ isomerisation reactions for both major $\mathrm{RO}_{2}$ species formed from the reaction of MVK with $\mathrm{OH}$ were investigated in detail by means of quantumchemical calculations.

Table 2 shows the reaction pathways that were examined for the $\mathrm{HMVKAO}_{2}$ and $\mathrm{HMVKBO}_{2}$ peroxy radicals. More information can be found in the Supplement. For both radicals, 1,5-H-migration of the hydroxyl $\mathrm{H}$-atom is energetically most favourable with a barrier of $22 \mathrm{kcal} \mathrm{mol}^{-1}$. The predicted reaction rate constant remains below $5 \times 10^{-4} \mathrm{~s}^{-1}$, mostly due to limited tunnelling owing to the large reaction endothermicity, and the broad energy barrier protruding less than $2 \mathrm{kcal} \mathrm{mol}^{-1}$ above the reaction products. The concomitant low energy barrier for the reverse $\mathrm{H}$-migration in the product implies that the reaction might be competitive against the alkoxy product decomposition with estimated barriers $4 \mathrm{kcal} \mathrm{mol}^{-1}$ (Vereecken and Peeters, 2009). Most of the other reactions considered are several orders of magnitude slower and can be neglected. The predicted rates for all processes considered remain over an order of magnitude below that required to fit the measured $\mathrm{OH}, \mathrm{HO}_{2}$ and glycolaldehyde concentrations so that these H-migration reactions do not have a discernible impact on the MVK oxidation chemistry radical budget or product yields at room temperature. As such, the subsequent chemistry after these reactions was not investigated.

The isomerisation rate constant estimated by Peeters et al. (2009) for Reaction (R6) of $0.01 \mathrm{~s}^{-1}$ is about two orders of magnitude faster than calculated here. This is mainly related to the higher energy barriers found at the levels of theory applied in this work. The small reaction rate constant for this reaction is consistent with the small product yield for methylglyoxal found in the low NO experiment, which would need to be significantly higher than calculated, if Reaction (R6) 
was competitive with the other $\mathrm{RO}_{2}$ reaction channels. A similar conclusion was drawn from product yields obtained in the study by Praske et al. (2015).

The fastest reaction rate coefficient of $\mathrm{RO}_{2}$ isomerisation reactions calculated here is found to be the $\mathrm{HMVKAO}_{2}$ 1,4-H-migration of the hydrogen atoms adjacent to the $-\mathrm{OH}$ group, followed by $\mathrm{H}$ abstraction at the $-\mathrm{OH}$ site by $\mathrm{O}_{2}$ forming $\mathrm{HO}_{2}$ together with a bi-ketone (named BIACETOOH in the MCM):

$\mathrm{HMVKAO}_{2}+\left(\mathrm{O}_{2}\right) \rightarrow \mathrm{HO}_{2}+$ BIACETOOH.

A reaction rate constant of $0.003 \mathrm{~s}^{-1}$ is calculated making this reaction competitive with the reaction of $\mathrm{HMVKAO}_{2}$ with $\mathrm{HO}_{2}$ and $\mathrm{NO}$ in the low $\mathrm{NO}$ experiments. Approximately 20 to $30 \%$ of the $\mathrm{HVMKAO}_{2}$ undergoes the 1,4$\mathrm{H}$ shift reaction in this experiment. However, the resulting increase of the $\mathrm{HO}_{2}$ concentration is rather small $(<$ $0.5 \times 10^{8} \mathrm{~cm}^{-3}$ ) because of the small $\mathrm{HMVKAO}_{2}$ yield in the reaction of MVK with $\mathrm{OH}$. This reaction is included in the model sensitivity runs M2.

\subsection{Potential additional $\mathrm{RO}_{2}$ reaction channel}

A fast conversion of $\mathrm{HMVKBO}_{2}$ to $\mathrm{HO}_{2}$ would be required to fit $\mathrm{HO}_{2}$ measurements. Glycolaldehyde would need to be a co-product to match measured values:

$\mathrm{HMVKBO}_{2}+(\mathrm{X}) \rightarrow \mathrm{HO}_{2}+$ products

$\mathrm{X}$ represents an unknown reaction partner not needed in case of a unimolecular reaction. M2 in Fig. 4 gives the model result, if Reaction (R8) is included in the $\mathrm{MCM}^{*}$ in addition to the 1,4-H shift of $\mathrm{HMVKAO}_{2}$ (Reaction R7) and the additional channels of the reaction of $\mathrm{HMVKBO}_{2}$ with $\mathrm{HO}_{2}$ (Reactions R3-R5).

In order to fit $\mathrm{HO}_{2}$ and glycolaldehyde concentration measurements, a reaction rate constant of $0.006 \pm 0.004 \mathrm{~s}^{-1}$ is required. This reaction rate makes the Reaction (R8) competitive with the reaction of $\mathrm{RO}_{2}$ with $\mathrm{NO}$ (reaction rate approximately $0.004 \mathrm{~s}^{-1}$ ) and $\mathrm{HO}_{2}$ (reaction rate approximately $0.008 \mathrm{~s}^{-1}$ ). In $\mathrm{M} 2,40 \%$ of $\mathrm{HMVKBO}_{2}$ reacts with $\mathrm{HO}_{2}$ and $30 \%$ of $\mathrm{HMVKBO}_{2}$ forms directly $\mathrm{HO}_{2}$ and glycolaldehyde in Reaction (R8) for conditions of this experiment. In comparison, $60 \%$ of $\mathrm{HMVKBO}_{2}$ reacts with $\mathrm{HO}_{2}$ in the model run M1. However, the overall effect on the $[\mathrm{OH}]$ is similar in both model runs so that modelled $[\mathrm{OH}]$ becomes consistent with measurements. This is due to the conversion of $\mathrm{HO}_{2}$ produced in Reaction (R8) to OH. Overall, however, the major difference in the results of $\mathrm{M} 1$ and $\mathrm{M} 2$ is in the improved model-measurement agreement of $\left[\mathrm{HO}_{2}\right]$.

Unfortunately, experiments here do not give hints about the exact nature of Reaction (R8). Quantum-chemical calculations (see above) shows that Reaction (R8) cannot be a unimolecular reaction such as $\mathrm{H}$-atom migration, because they are not fast enough to compete with other $\mathrm{RO}_{2}$ reaction channels. Photolysis of $\mathrm{RO}_{2}$ that could results in $\mathrm{OH} / \mathrm{HO}_{2}$ have been observed for acetylperoxy radicals (Cox et al., 1990) and isoprene derived $\mathrm{RO}_{2}$ (Hansen et al., 2017). However, the reaction rate constant of $0.006 \pm 0.004 \mathrm{~s}^{-1}$ needed here to explain observations would require an unrealistically high absorption cross section. A reaction partner in Reaction (R8) could also be a $\mathrm{RO}_{2}$ radical. However, in this case products of the $\mathrm{HMVKBO}_{2}$ plus $\mathrm{RO}_{2}$ reaction that are assumed in the MCM would need to be changed according to Reaction (R8) and the reaction rate constant would need to be increased by a large factor of 20 to 50 compared to recommendations for $\mathrm{RO}_{2}$ self-reaction rate constants in order to make this reaction competitive with the other $\mathrm{RO}_{2}$ reaction channels.

\subsection{Model-measurement agreement of nitrogen oxide species}

So far, only radicals and organic products have been discussed. However, there is also disagreement between measured and modelled $\mathrm{NO}_{2}$ mixing ratios. The $\mathrm{NO}_{2}$ concentration produced by the model is $30 \%$ smaller in the low NO experiment (23 May 2017)) compared to measured values. This discrepancy increases to $40 \%$, if the $\mathrm{OH}$ concentration and therefore the MVK oxidation rate is increased. This is due to the increased production of peroxy radicals, which form peroxy acyl nitrate (PAN) or PAN like species, which act as nitrogen oxide reservoirs. Acetylperoxy radicals forming PAN are mainly produced from $\mathrm{HVMKBO}_{2}$ as a co-product of glycolaldehyde, but another PAN-like species (MCM name PHAN) is additionally produced by the oxidation of glycolaldehyde. If no production of PHAN is assumed, measured and modelled $\mathrm{NO}_{2}$ mixing ratios agree within 100 pptv (M2 in Fig. 4), less than the accuracy of the $\mathrm{NO}_{x}$ formation in the chamber. However, also reduction of the production of acetylperoxy radicals could improve the model-measurement agreement. The change in NO and peroxy radical concentrations is rather small, because of the suppression of $\mathrm{NO}$ by $\mathrm{O}_{3}$ and the overall small turnover rate of $\mathrm{HO}_{2}$ and $\mathrm{NO}$. More specific experiments concerning the $\mathrm{NO}_{x}$ budget would be required to decide, which $\mathrm{NO}_{x}$ reservoir species is overestimated by the model.

\subsection{OH budget analysis}

$\mathrm{OH}$ is in steady state because of its short lifetime, so that its rates of production and destruction are equal. Therefore, $\mathrm{OH}$ reactivity together with $\mathrm{OH}$ concentration measurements allows determination of the total $\mathrm{OH}$ production rate from only two measured quantities. Under conditions with high NO concentrations, only few chemical reactions are typically controlling the $\mathrm{OH}$ production. The dominating process is usually the recycling of $\mathrm{HO}_{2}$ by its reaction with NO. In addition, photolysis of ozone and HONO make significant contributions. For low NO conditions and in the presence of high VOC concentrations, field and chamber experiments often show larger total $\mathrm{OH}$ productions rates (derived from mea- 


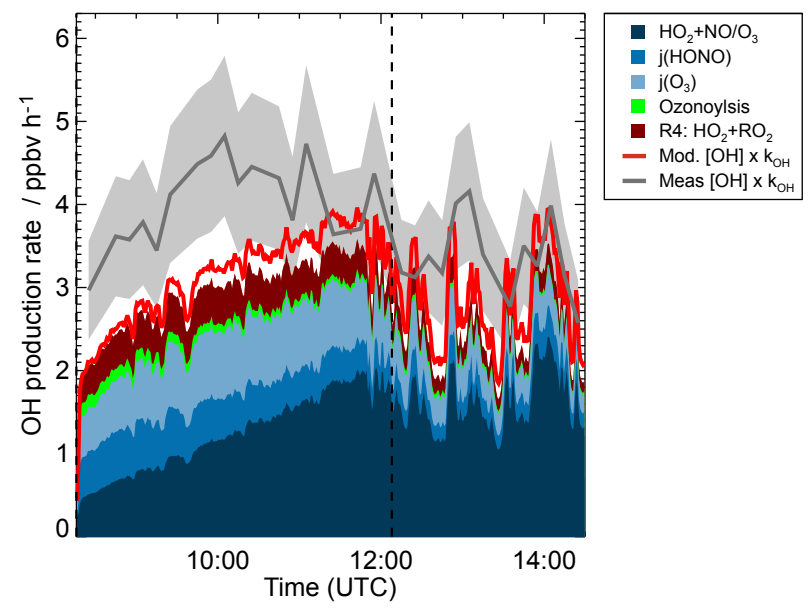

Figure 5. OH budget during the experiment at low NO concentration (23 May 2017) for the period, when MVK photooxidation took place. The vertical dashed line indicates when MVK was reinjected into the chamber. Red and blue coloured areas add contributions to the $\mathrm{OH}$ production calculated from the model results (M2 sensitivity run in Fig. 4). The contribution $\mathrm{RO}_{2}+\mathrm{HO}_{2}$ refers to the $\mathrm{OH}$ production from Reaction (R4). In addition to modelled $\mathrm{OH}$ production contributions, total $\mathrm{OH}$ production calculated from the product of $\mathrm{OH}$ concentration and $\mathrm{OH}$ reactivity $\left(k_{\mathrm{OH}}\right)$ is shown. These quantities are either taken from the model results (M2) or from measurements. The coloured grey area gives the uncertainty of the total $\mathrm{OH}$ production calculation, if measured $\mathrm{OH}$ concentrations and measured $\mathrm{OH}$ reactivity are used.

sured $\mathrm{OH}$ and $\mathrm{OH}$ reactivity) than can be explained by the above processes. Under these conditions, other $\mathrm{OH}$ sources linked to the degradation of VOCs become relevant.

Figure 5 shows the $\mathrm{OH}$ budget for the low NO experiment (23 May 2017) using model results (M2, Table 1) to calculate contributions to the $\mathrm{OH}$ production. In addition, total $\mathrm{OH}$ production is calculated from measured and modelled $\mathrm{OH}$ concentrations and $\mathrm{OH}$ reactivity. Results from calculations using either modelled or measured values give similar numbers that agree within the uncertainty of the calculation of $20 \%$.

The $\mathrm{OH}$ production rate is dominated by $\mathrm{HO}_{2}$ recycling reactions and primary $\mathrm{OH}$ production ( $\mathrm{HONO}$ and $\mathrm{O}_{3}$ photolysis). These contributions explain 70 to $80 \%$ of the total $\mathrm{OH}$ production during the MVK oxidation. The model would give lower $\mathrm{OH}$ production compared to calculations using measurements if Reaction (R8) was not included because $\mathrm{HO}_{2}$ concentrations and therefore $\mathrm{OH}$ recycling by $\mathrm{HO}_{2}$ would be underpredicted in this case. This reaction is responsible for approximately half of the $\mathrm{HO}_{2}$ concentration during the first $2 \mathrm{~h}$ of MVK oxidation. This demonstrates the importance of including all $\mathrm{HO}_{2}$ sources in models.

Another 10 to $15 \%$ of the total $\mathrm{OH}$ production rate is due to the $\mathrm{OH}$ formation from the additional $\mathrm{HO}_{2}$ plus $\mathrm{RO}_{2}$ reaction channel suggested by Praske et al. (2015) (Reaction R4).
A large number of other $\mathrm{OH}$ forming reactions included in the model such as photolysis of hydroxyperoxides fills the remaining gap between these major contributions and the total calculated $\mathrm{OH}$ production.

\section{Summary and conclusions}

The photooxidation of MVK, one of the major oxidation products of isoprene, was investigated at atmospheric conditions in the simulation chamber SAPHIR. NO was varied from high to low concentrations. For high $\mathrm{NO}, \mathrm{RO}_{2}$ is mainly lost in the reaction with $\mathrm{NO}$ and current chemical models can describe radical concentrations within $20 \%$. Product yields of the major oxidation products glycolaldehyde $(0.65 \pm 0.14)$ and methylglyoxal $(0.19 \pm 0.03)$ are consistent with previous measurements (Tuazon and Atkinson, 1989; Galloway et al., 2011; Praske et al., 2015).

$\mathrm{OH}$ radical concentrations are underestimated (maximum factor 2) by the MCM at low NO concentrations (< 100 pptv), when other $\mathrm{RO}_{2}$ reaction channels can compete with the reaction of $\mathrm{RO}_{2}$ with NO. At the same time, also $\mathrm{HO}_{2}$ and glycolaldehyde concentrations are smaller in the model compared to measurements. Only part of the modelmeasurements discrepancies can be explained by findings in recent studies investigating the MVK photooxidation. The higher glycolaldehyde yield is consistent with a study by Praske et al. (2015). The additional channels for the $\mathrm{RO}_{2}$ plus $\mathrm{HO}_{2}$ reaction suggested by these authors can reproduce glycolaldehyde and $\mathrm{OH}$ concentrations, but do not explain the model-measurement discrepancy for $\left[\mathrm{HO}_{2}\right]$.

The possibility of $\mathrm{RO}_{2}$ isomerisation reactions for both major $\mathrm{RO}_{2}$ species formed from the reaction of MVK with $\mathrm{OH}$ were investigated in detail by means of quantumchemical calculations. Additional $\mathrm{HO}_{2}$ can be produced from the $1,4-\mathrm{H}$ shift reaction of $\mathrm{HVMKAO}_{2}$. The reaction rate constant of $0.003 \mathrm{~s}^{-1}$ is competitive with other $\mathrm{RO}_{2}$ reaction channels at low NO conditions. The overall impact, however, is small due to the small $\mathrm{HMVKAO}_{2}$ yield. Other reactions considered here can be neglected for atmospheric conditions. This also includes the isomerisation reaction suggested by Peeters et al. (2009) (Reaction R6). The rate constant for this reaction is about two orders of magnitude smaller than calculated by Peeters et al. (2009) due to the higher energy barriers found at the higher levels of theory applied in this work.

Because $\mathrm{HO}_{2}$ and glycolaldehyde concentrations are underestimated at the same time, a reaction that converts $\mathrm{RO}_{2}$ to $\mathrm{HO}_{2}$ and glycolaldehyde (Reaction R8) would explain observations in these experiments. A reaction rate constant of $0.006 \pm 0.004 \mathrm{~s}^{-1}$ is required to bring measured and modelled values into agreement. Unimolecular $\mathrm{H}$-shift reactions are found to be too slow. Alternatively, reaction of $\mathrm{HMVKBO}_{2}$ with $\mathrm{RO}_{2}$ that would produce directly $\mathrm{HO}_{2}$ and glycolaldehyde would explain $\left[\mathrm{HO}_{2}\right]$ observations and would give similar $\mathrm{OH}$ and glycolaldehyde concentrations as the mecha- 
nism by Praske et al. (2015). However, more than the product species would need to be different from what is described in the MCM, but also the reaction rate constants would need to be increased by a large factor of 20 to 50 for the $\mathrm{HMVKBO}_{2}$ plus $\mathrm{RO}_{2}$ reaction. More studies will be needed to explore the exact role of $\mathrm{HO}_{2}$ in the MVK oxidation scheme. In addition, open questions remain concerning the fate of nitrogen oxides in the MVK oxidation scheme. The MCM suggests the built-up of nitrogen oxide reservoirs by the formation of PAN and PAN-like species. Experiments here indicate that these reservoirs are less important.

The need for an additional $\mathrm{HO}_{2}$ source was also found in the oxidation of monoterpenes. Field studies, in which $\mathrm{OH}$ reactivity was dominated by monoterpenes, showed that models underestimate $\mathrm{HO}_{2}$ and $\mathrm{OH}$ concentrations (Kim et al., 2013; Hens et al., 2014). A chamber study investigating the photochemistry of $\beta$-pinene found that an additional $\mathrm{HO}_{2}$ source is required to explain observed $\mathrm{HO}_{2}$ and $\mathrm{OH}$ and suggested a rearrangement of radical intermediates as explanation (Kaminski et al., 2017).

The impact on the $\mathrm{OH}$ recycling efficiency and observed organic products in the MVK oxidation are the same regardless whether $\mathrm{OH}$ is directly produced from $\mathrm{HO}_{2}$ plus $\mathrm{RO}_{2}$ like in the Praske et al. (2015) mechanism or if $\mathrm{OH}$ is produced from enhanced $\mathrm{HO}_{2}$ as suggested by experiments here. The enhanced $\mathrm{OH}$ recycling is demonstrated in this study by the direct quantification of the $\mathrm{OH}$ radical concentration during the photochemical oxidation of MVK. Similar as for isoprene (Peeters et al., 2014; Fuchs et al., 2013) and the second major organic product from isoprene oxidation, methacrolein, (Crounse et al., 2011; Fuchs et al., 2014), $\mathrm{HO}_{x}$ radicals are faster recycled in the MVK oxidation scheme than previously assumed. For all three species, $\mathrm{OH}$ concentrations are found to be a factor of 2 to 3 higher than calculated by models for atmospheric conditions with low NO concentrations. Current state-of-the-art models increased already $\mathrm{OH}$ production for isoprene and methacrolein oxidation by including additional reaction pathways. The study here shows that this is also needed for the MVK oxidation scheme.

Data availability. Data of the experiments in the SAPHIR chamber used in this work is available on the EUROCHAMP data homepage (https://data.eurochamp.org/, last access: April 2018).

Supplement. The supplement related to this article is available online at: https://doi.org/10.5194/acp-18-8001-2018-supplement.

Competing interests. The authors declare to have no competing interests.
Acknowledgements. This project has received funding from the European Research Council (ERC) under the European Union's Horizon 2020 research and innovation programme (SARLEP grant agreement No. 681529) and from the European Commission (EC) under the European Union's Horizon 2020 research and innovation programme (Eurochamp 2020 grant agreement No. 730997). The authors thank the Forschungszentrum Jülich for travel support under the project "Seed Money". Frank N. Keutsch and Alex Zaytsev were supported by the National Science Foundation (AGS 1628491 and 1628530). Martin Breitenlechner was supported by the Austrian Science Fund (FWF), Erwin Schrödinger Stipendium, Grant No. J-3900. The authors thank Thomas Mentel, Yare Baker and Sungah Kang from Forschungszentrum Jülich for supporting the $\mathrm{HO}_{2}$ CIMS measurements.

The article processing charges for this open-access publication were covered by a Research

Centre of the Helmholtz Association.

Edited by: Sergey A. Nizkorodov

Reviewed by: two anonymous referees

\section{References}

Aschmann, S. M., Arey, J., and Atkinson, R.: OH radical formation from the gas-phase reactions of $\mathrm{O}_{3}$ with methacrolein and methyl vinyl ketone, Atmos. Environ., 30, 2939-2943, https://doi.org/10.1016/1352-2310(96)00013-1, 1996.

Atkinson, R., Baulch, D. L., Cox, R. A., Crowley, J. N., Hampson, R. F., Hynes, R. G., Jenkin, M. E., Rossi, M. J., Troe, J., and Subcommittee, I.: Evaluated kinetic and photochemical data for atmospheric chemistry: Volume II - gas phase reactions of organic species, Atmos. Chem. Phys., 6, 3625-4055, https://doi.org/10.5194/acp-6-3625-2006, 2006.

Bohn, B. and Zilken, H.: Model-aided radiometric determination of photolysis frequencies in a sunlit atmosphere simulation chamber, Atmos. Chem. Phys., 5, 191-206, https://doi.org/10.5194/acp-5-191-2005, 2005.

Bohn, B., Rohrer, F., Brauers, T., and Wahner, A.: Actinometric measurements of $\mathrm{NO}_{2}$ photolysis frequencies in the atmosphere simulation chamber SAPHIR, Atmos. Chem. Phys., 5, 493-503, https://doi.org/10.5194/acp-5-493-2005, 2005.

Cox, R. A., Munk, J., Nielsen, O. J., Pagsberg, P., and Ratajczak, E.: Ultraviolet absorption spectra and kinetics of acetonyl and acetonylperoxy radicals, Chem. Phys. Lett., 173, 206-210, https://doi.org/10.1016/0009-2614(90)80079-S, 1990.

Crounse, J. D., Paulot, F., Kjaergaard, H. G., and Wennberg, P. O.: Peroxy radical isomerization in the oxidation of isoprene, Phys. Chem. Chem. Phys., 13, 13607-13613, https://doi.org/10.1039/C1CP21330J, 2011.

Crounse, J. D., Knap, H. C., Ornso, K. B., Jorgensen, S., Paulot, F., Kjaergaard, H. G., and Wennberg, P. O.: On the atmospheric fate of methacrolein: 1. Peroxy radical isomerization following addition of $\mathrm{OH}$ and $\mathrm{O}_{2}$, J. Phys. Chem. A, 116, 5756-5762, https://doi.org/10.1021/jp211560u, 2012.

D’Ambro, E. L., Moller, K. H., Lopez-Hilfiker, F. D., Schobesberger, S., Liu, J., Shilling, J. E., Lee, B. H., Kjaergaard, H. G., and Thornton, J. A.: Isomerization of second-generation isoprene 
peroxy radicals: epoxide formation and implications for secondary organic aerosol yields, Environ Sci. Technol., 51, 49784987, https://doi.org/10.1021/acs.est.7b00460, 2017.

Dillon, T. J. and Crowley, J. N.: Direct detection of OH formation in the reactions of $\mathrm{HO}_{2}$ with $\mathrm{CH}_{3} \mathrm{C}(\mathrm{O}) \mathrm{O}_{2}$ and other substituted peroxy radicals, Atmos. Chem. Phys., 8, 4877-4889, https://doi.org/10.5194/acp-8-4877-2008, 2008.

Dorn, H.-P., Brandenburger, U., Brauers, T., and Hausmann, M.: A new in-situ laser long-path absorption instrument for the measurement of tropospheric $\mathrm{OH}$ radicals, J. Atmos. Sci., 52, 33733380, 1995.

Dunning, T. H.: Gaussian basis sets for use in correlated molecular calculations. I. The atoms boron through neon and hydrogen, J. Chem. Phys., 90, 1007-1023, https://doi.org/10.1063/1.456153, 1989.

Eurochamp: Database of Atmospheric Simulation Chamber Studies, available at: https://data.eurochamp.org/data-access/ chamber-experiments/, last accesss: April 2018.

Frisch, M. J., Trucks, G. W., Schlegel, H. B., Scuseria, G. E., Robb, M. A., Cheeseman, J. R., Scalmani, G., Barone, V., Mennucci, B., Petersson, G. A., Nakatsuji, H., Caricato, M., Li, X., Hratchian, H. P., Izmaylov, A. F., Bloino, J., Zheng, G., Sonnenberg, J. L., Hada, M., Ehara, M., Toyota, K., Fukuda, R., Hasegawa, J., Ishida, M., Nakajima, T., Honda, Y., Kitao, O., Nakai, H., Vreven, T., A., M. J. J., Peralta, J. E., Ogliaro, F., Bearpark, M., Heyd, J. J., Brothers, E., Kudin, K. N., Staroverov, V. N., Keith, T., Kobayashi, R., Normand, J., Normand, J., Raghavachari, K., Rendell, A., Burant, J. C., Iyengar, S. S., Tomasi, J., Cossi, M., Rega, N., Millam, J. M., Klene, M., Knox, J. E., Cross, J. B., Bakken, V., Adamo, C., Jaramillo, J., Gomperts, R., Stratmann, R. E., Yazyev, O., Austin, A. J., Cammi, R., Pomelli, C., Ochterski, J. W., Martin, R. L., Morokuma, K., Zakrzewski, V. G., Voth, G. A., Salvador, P., Dannenberg, J. J., Dapprich, S., Daniels, A. D., Farkas, O., Foresman, J. B., Ortiz, J. V., Cioslowski, J., Fox, D. J., and Pople, J. A.: Gaussian 09, Revision B.01, Gaussian Inc., Wallington CT., 2010.

Fuchs, H., Hofzumahaus, A., and Holland, F.: Measurement of tropospheric $\mathrm{RO}_{2}$ and $\mathrm{HO}_{2}$ radicals by a laser-induced fluorescence instrument, Rev. Sci. Instrum., 79, 084104, https://doi.org/10.1063/1.2968712, 2008.

Fuchs, H., Dube, W. P., Lerner, B. M., Wagner, N. L., Williams, E. J., and Brown, S. S.: A sensitive and versatile detector for atmospheric $\mathrm{NO}_{2}$ and $\mathrm{NO}_{x}$ based on blue diode laser cavity ring-down spectroscopy, Environ. Sci. Technol., 43, 7831-7836, https://doi.org/10.1021/es902067h, 2009.

Fuchs, H., Bohn, B., Hofzumahaus, A., Holland, F., Lu, K. D., Nehr, S., Rohrer, F., and Wahner, A.: Detection of $\mathrm{HO}_{2}$ by laser-induced fluorescence: calibration and interferences from $\mathrm{RO}_{2}$ radicals, Atmos. Meas. Tech., 4, 1209-1255, https://doi.org/10.5194/amt-4-1209-2011, 2011.

Fuchs, H., Dorn, H. P., Bachner, M., Bohn, B., Brauers, T., Gomm, S., Hofzumahaus, A., Holland, F., Nehr, S., Rohrer, F., Tillmann, R., and Wahner, A.: Comparison of $\mathrm{OH}$ concentration measurements by DOAS and LIF during SAPHIR chamber experiments at high $\mathrm{OH}$ reactivity and low NO concentration, Atmos. Meas. Tech., 5, 1611-1626, https://doi.org/10.5194/amt-5-1611-2012, 2012.

Fuchs, H., Hofzumahaus, A., Rohrer, F., Bohn, B., Brauers, T., Dorn, H.-P., Häseler, R., Holland, F., Kaminski, M., Li, X.,
Lu, K., Nehr, S., Tillmann, R., Wegener, R., and Wahner, A.: Experimental evidence for efficient hydroxyl radical regeneration in isoprene oxidation, Nat. Geosci., 6, 1023-1026, https://doi.org/10.1038/NGEO1964, 2013.

Fuchs, H., Acir, I. H., Bohn, B., Brauers, T., Dorn, H. P., Häseler, R., Hofzumahaus, A., Holland, F., Kaminski, M., Li, X., Lu, K., Lutz, A., Nehr, S., Rohrer, F., Tillmann, R., Wegener, R., and Wahner, A.: $\mathrm{OH}$ regeneration from methacrolein oxidation investigated in the atmosphere simulation chamber SAPHIR, Atmos. Chem. Phys., 14, 7895-7908, https://doi.org/10.5194/acp14-7895-2014, 2014.

Fuchs, H., Tan, Z., Hofzumahaus, A., Broch, S., Dorn, H. P., Holland, F., Künstler, C., Gomm, S., Rohrer, F., Schrade, S., Tillmann, R., and Wahner, A.: Investigation of potential interferences in the detection of atmospheric $\mathrm{RO}_{X}$ radicals by laserinduced fluorescence under dark conditions, Atmos. Meas. Tech., 9, 1431-1447, https://doi.org/10.5194/amt-9-1431-2016, 2016.

Fuchs, H., Novelli, A., Rolletter, M., Hofzumahaus, A., Pfannerstill, E. Y., Kessel, S., Edtbauer, A., Williams, J., Michoud, V., Dusanter, S., Locoge, N., Zannoni, N., Gros, V., Truong, F., SardaEsteve, R., Cryer, D. R., Brumby, C. A., Whalley, L. K., Stone, D., Seakins, P. W., Heard, D. E., Schoemaecker, C., Blocquet, M., Coudert, S., Batut, S., Fittschen, C., Thames, A. B., Brune, W. H., Ernest, C., Harder, H., Muller, J. B. A., Elste, T., Kubistin, D., Andres, S., Bohn, B., Hohaus, T., Holland, F., Li, X., Rohrer, F., Kiendler-Scharr, A., Tillmann, R., Wegener, R., Yu, Z., Zou, Q., and Wahner, A.: Comparison of $\mathrm{OH}$ reactivity measurements in the atmospheric simulation chamber SAPHIR, Atmos. Meas. Tech., 10, 4023-4053, https://doi.org/10.5194/amt10-4023-2017, 2017.

Galloway, M. M., Huisman, A. J., Yee, L. D., Chan, A. W. H., Loza, C. L., Seinfeld, J. H., and Keutsch, F. N.: Yields of oxidized volatile organic compounds during the $\mathrm{OH}$ radical initiated oxidation of isoprene, methyl vinyl ketone, and methacrolein under high-NO ${ }_{X}$ conditions, Atmos. Chem. Phys., 11, 10779-10790, https://doi.org/10.5194/acp-11-10779-2011, 2011.

Grosjean, D., Williams, E. L., and Grosjean, E.: Atmospheric chemistry of isoprene and of its carbonyl products, Environ Sci. Technol., 27, 830-840, https://doi.org/10.1021/es00042a004, 1993.

Guenther, A. B., Jiang, X., Heald, C. L., Sakulyanontvittaya, T., Duhl, T., Emmons, L. K., and Wang, X.: The model of emissions of gases and aerosols from nature version 2.1 (MEGAN2.1): an extended and updated framework for modeling biogenic emissions, Geosci. Model Dev., 5, 1471-1492, https://doi.org/10.5194/gmd-5-1471-2012, 2012.

Hansen, R. F., Lewis, T. R., Graham, L., Whalley, L. K., Seakins, P. W., Heard, D. E., and Blitz, M. A.: OH production from the photolysis of isoprene-derived peroxy radicals: cross-sections, quantum yields and atmospheric implications, Phys. Chem. Chem. Phys., 19, 2332-2345, https://doi.org/10.1039/C6CP06718B, 2017.

Hens, K., Novelli, A., Martinez, M., Auld, J., Axinte, R., Bohn, B., Fischer, H., Keronen, P., Kubistin, D., Nölscher, A. C., Oswald, R., Paasonen, P., Petäjä, T., Regelin, E., Sander, R., Sinha, V., Sipilä, M., Taraborrelli, D., Tatum Ernest, C., Williams, J., Lelieveld, J., and Harder, H.: Observation and modelling of $\mathrm{HO}_{X}$ radicals in a boreal forest, Atmos. Chem. Phys., 14, 8723-8747, https://doi.org/10.5194/acp-14-8723-2014, 2014. 
Hofzumahaus, A., Rohrer, F., Lu, K., Bohn, B., Brauers, T., Chang, C.-C., Fuchs, H., Holland, F., Kita, K., Kondo, Y., Li, X., Lou, S., Shao, M., Zeng, L., Wahner, A., and Zhang, Y.: Amplified trace gas removal in the troposphere, Science, 324, 1702-1704, https://doi.org/10.1126/science.1164566, 2009.

Kaminski, M., Fuchs, H., Acir, I. H., Bohn, B., Brauers, T., Dorn, H. P., Häseler, R., Hofzumahaus, A., Li, X., Lutz, A., Nehr, S., Rohrer, F., Tillmann, R., Vereecken, L., Wegener, R., and Wahner, A.: Investigation of the $\beta$-pinene photooxidation by $\mathrm{OH}$ in the atmosphere simulation chamber SAPHIR, Atmos. Chem. Phys., 17, 6631-6650, https://doi.org/10.5194/acp-176631-2017, 2017.

Karl, M., Dorn, H.-P., Holland, F., Koppmann, R., Poppe, D., Rupp, L., Schaub, A., and Wahner, A.: Product study of the reaction of $\mathrm{OH}$ radicals with isoprene in the atmosphere simulation chamber SAPHIR, J. Atmos. Chem., 55, 167-187, https://doi.org/10.1007/s10874-006-9034-x, 2006.

Karunanandan, R., Hölscher, D., Dillon, T. J., Horowitz, A., Crowley, J. N., Vereecken, L., and Peeters, J.: Reaction of $\mathrm{HO}$ with glycolaldehyde $\mathrm{HOCH}_{2} \mathrm{CHO}$ : Rate coefficients (240$362 \mathrm{~K})$ and mechanism, J. Chem. Phys. A, 111, 897-908, https://doi.org/10.1021/jp0649504, 2007.

Kim, S., Wolfe, G. M., Mauldin, L., Cantrell, C., Guenther, A., Karl, T., Turnipseed, A., Greenberg, J., Hall, S. R., Ullmann, K., Apel, E., Hornbrook, R., Kajii, Y., Nakashima, Y., Keutsch, F. N., DiGangi, J. P., Henry, S. B., Kaser, L., Schnitzhofer, R., Graus, M., and Hansel, A.: Evaluation of $\mathrm{HO}_{X}$ sources and cycling using measurement-constrained model calculations in a 2-methyl-3-butene-2-ol (MBO) and monoterpene (MT) dominated ecosystem, Atmos. Chem. Phys., 13, 2031-2044, https://doi.org/10.5194/acp-13-2031-2013, 2013.

Lelieveld, J., Butler, T. M., Crowley, J. N., Dillon, T. J., Fischer, H., Ganzeveld, L., Harder, H., Lawrence, M. G., Martinez, M., Taraborrelli, D., and Williams, J.: Atmospheric oxidation capacity sustained by a tropical forest, Nature, 452, 737-740, https://doi.org/10.1038/nature06870, 2008.

Lew, M. M., Dusanter, S., and Stevens, P. S.: Measurement of interferences associated with the detection of the hydroperoxy radical in the atmosphere using laser-induced fluorescence, Atmos. Meas. Tech., 11, 95-108, https://doi.org/10.5194/amt-1195-2018, 2018.

Lou, S., Holland, F., Rohrer, F., Lu, K., Bohn, B., Brauers, T., Chang, C. C., Fuchs, H., Häseler, R., Kita, K., Kondo, Y., Li, X., Shao, M., Zeng, L., Wahner, A., Zhang, Y., Wang, W., and Hofzumahaus, A.: Atmospheric $\mathrm{OH}$ reactivities in the Pearl River Delta - China in summer 2006: measurement and model results, Atmos. Chem. Phys., 10, 11243-11260, https://doi.org/10.5194/acp-10-11243-2010, 2010.

Lu, K. D., Rohrer, F., Holland, F., Fuchs, H., Bohn, B., Brauers, T., Chang, C. C., Häseler, R., Hu, M., Kita, K., Kondo, Y., Li, X., Lou, S. R., Nehr, S., Shao, M., Zeng, L. M., Wahner, A., Zhang, Y. H., and Hofzumahaus, A.: Observation and modelling of $\mathrm{OH}$ and $\mathrm{HO}_{2}$ concentrations in the Pearl River Delta 2006: a missing $\mathrm{OH}$ source in a VOC rich atmosphere, Atmos. Chem. Phys., 12, 1541-1569, https://doi.org/10.5194/acp-12-1541-2012, 2012.

Mao, J., Ren, X., Brune, W. H., Van Duin, D. M., Cohen, R. C., Park, J. H., Goldstein, A. H., Paulot, F., Beaver, M. R., Crounse, J. D., Wennberg, P. O., DiGangi, J. P., Henry, S. B., Keutsch, F. N., Park, C., Schade, G. W., Wolfe, G. M., and Thornton,
J. A.: Insights into hydroxyl measurements and atmospheric oxidation in a California forest, Atmos. Chem. Phys., 12, 80098020, https://doi.org/10.5194/acp-12-8009-2012, 2012.

Martin, J. M. L.: Ab initio total atomization energies of small molecules - towards the basis set limit, Chem. Phys. Lett., 259, 669-678, https://doi.org/10.1016/0009-2614(96)00898-6, 1996.

MCM: Master Chemical Mechanism, available at: http://mcm. leeds.ac.uk/MCM/, last access: May 2017.

Nölscher, A. C., Williams, J., Sinha, V., Custer, T., Song, W., Johnson, A. M., Axinte, R., Bozem, H., Fischer, H., Pouvesle, N., Phillips, G., Crowley, J. N., Rantala, P., Rinne, J., Kulmala, M., Gonzales, D., Valverde-Canossa, J., Vogel, A., Hoffmann, T., Ouwersloot, H. G., Vila-Guerau de Arellano, J., and Lelieveld, J.: Summertime total $\mathrm{OH}$ reactivity measurements from boreal forest during HUMPPA-COPEC 2010, Atmos. Chem. Phys., 12, 8257-8270, https://doi.org/10.5194/acp-12-8257-2012, 2012.

Novelli, A., Hens, K., Tatum Ernest, C., Kubistin, D., Regelin, E., Elste, T., Plass-Dülmer, C., Martinez, M., Lelieveld, J., and Harder, H.: Characterisation of an inlet pre-injector laserinduced fluorescence instrument for the measurement of atmospheric hydroxyl radicals, Atmos. Meas. Tech., 7, 3413-3430, https://doi.org/10.5194/amt-7-3413-2014, 2014.

Paulson, S. E., Chung, M., Sen, A. D., and Orzechowska, G.: Measurement of $\mathrm{OH}$ radical formation from the reaction of ozone with several biogenic alkenes, J. Geophys. Res., 103, 2553325539, https://doi.org/10.1029/98JD01951, 1998.

Peeters, J., Nguyen, T. L., and Vereecken, L.: $\mathrm{HO}_{X}$ radical regeneration in the oxidation of isoprene, Phys. Chem. Chem. Phys., 11, 5935-5939, https://doi.org/10.1039/b908511d, 2009.

Peeters, J., Müller, J.-F., Stavrakou, T., and Nguyen, V. S.: Hydroxyl radical recycling in isoprene oxidation driven by hydrogen bonding and hydrogen tunneling: The upgraded LIM1 mechanism, J. Phys. Chem. A, 118, 8625-8643, https://doi.org/10.1021/jp5033146, 2014.

Praske, E., Crounse, J. D., Bates, K. H., Kurten, T., Kjaergaard, H. G., and Wennberg, P. O.: Atmospheric fate of methyl vinyl ketone: Peroxy radical reactions with $\mathrm{NO}$ and $\mathrm{HO}_{2}$, J. Phys. Chem. A, 119, 4562-4572, https://doi.org/10.1021/jp5107058, 2015.

Purvis, G. D. and Bartlett, R. J.: A full coupled-cluster singles and doubles model: The inclusion of disconnected triples, J. Chem. Phys., 76, 1910-1918, https://doi.org/10.1063/1.443164, 1982.

Rickly, P. and Stevens, P. S.: Measurements of a potential interference with laser-induced fluorescence measurements of ambient $\mathrm{OH}$ from the ozonolysis of biogenic alkenes, Atmos. Meas. Tech., 11, 1-16, https://doi.org/10.5194/amt-11-1-2018, 2018.

Rohrer, F., Bohn, B., Brauers, T., Brüning, D., Johnen, F.-J., Wahner, A., and Kleffmann, J.: Characterisation of the photolytic HONO-source in the atmosphere simulation chamber SAPHIR, Atmos. Chem. Phys., 5, 2189-2201, https://doi.org/10.5194/acp5-2189-2005, 2005.

Sanchez, J., Tanner, D. J., Chen, D., Huey, L. G., and Ng, N. L.: A new technique for the direct detection of $\mathrm{HO}_{2}$ radicals using bromide chemical ionization mass spectrometry (Br-CIMS): initial characterization, Atmos. Meas. Tech., 9, 3851-3861, https://doi.org/10.5194/amt-9-3851-2016, 2016.

Schlosser, E., Brauers, T., Dorn, H.-P., Fuchs, H., Häseler, R., Hofzumahaus, A., Holland, F., Wahner, A., Kanaya, Y., Kajii, Y., Miyamoto, K., Nishida, S., Watanabe, K., Yoshino, A., Kubistin, D., Martinez, M., Rudolf, M., Harder, H., Berresheim, H., 
Elste, T., Plass-Dülmer, C., Stange, G., and Schurath, U.: Technical Note: Formal blind intercomparison of $\mathrm{OH}$ measurements: results from the international campaign HOxComp, Atmos. Chem. Phys., 9, 7923-7948, https://doi.org/10.5194/acp-9-7923-2009, 2009.

St. Clair, J. M., Rivera, J. C., Crounse, J. D., Knap, H. C., Bates, K. H., Teng, A. P., Jørgensen, S., Kjaergaard, H. G., Keutsch, F. N., and Wennberg, P. O.: Kinetics and products of the reaction of the first-generation isoprene hydroxy hydroperoxide (ISOPOOH) with OH, J. Phys. Chem. A, 120, 1441-1451, https://doi.org/10.1021/acs.jpca.5b06532, 2015.

Tan, D., Faloona, I., Simpas, J. B., Brune, W., Shepson, P. B., Couch, T. L., Summer, A. L., Carroll, M. A., Thornberry, T., Apel, E., Riemer, D., and Stockwell, W.: $\mathrm{HO}_{X}$ budget in a deciduous forest: results from the PROPHET summer 1998 campaign, J. Geophys. Res., 106, 24407-24427, https://doi.org/10.1029/2001JD900016, 2001.

Tuazon, E. C. and Atkinson, R.: A product study of the gasphase reaction of methyl vinyl ketone with the $\mathrm{OH}$ radical in the presence of $\mathrm{NO}_{X}$, Int. J. Chem. Kin., 21, 1141-1152, https://doi.org/10.1002/kin.550211207, 1989.

Vereecken, L. and Peeters, J.: The 1,5-H-shift in 1-butoxy: A case study in the rigorous implementation of transition state theory for a multirotamer system, J. Chem. Phys., 119, 5159-5170, https://doi.org/10.1063/1.1597479, 2003.

Vereecken, L. and Peeters, J.: Decomposition of substituted alkoxy radicals-part I: a generalized structure-activity relationship for reaction barrier heights, Phys. Chem. Chem. Phys., 11, 90629074, https://doi.org/10.1039/B909712K, 2009.

Veres, P. R., Roberts, J. M., Wild, R. J., Edwards, P. M., Brown, S. S., Bates, T. S., Quinn, P. K., Johnson, J. E., Zamora, R. J., and de Gouw, J.: Peroxynitric acid $\left(\mathrm{HO}_{2} \mathrm{NO}_{2}\right)$ measurements during the UBWOS 2013 and 2014 studies using iodide ion chemical ionization mass spectrometry, Atmos. Chem. Phys., 15, 81018114, https://doi.org/10.5194/acp-15-8101-2015, 2015.

Wennberg, P. O., Bates, K. H., Crounse, J. D., Dodson, L. G., McVay, R. C., Mertens, L. A., Nguyen, T. B., Praske, E., Schwantes, R. H., Smarte, M. D., St Clair, J. M., Teng, A. P., Zhang, X., and Seinfeld, J. H.: Gas-Phase reactions of isoprene and its major oxidation products, Chem. Rev., 18, 3337-3390, https://doi.org/10.1021/acs.chemrev.7b00439, 2018.
Whalley, L. K., Edwards, P. M., Furneaux, K. L., Goddard, A., Ingham, T., Evans, M. J., Stone, D., Hopkins, J. R., Jones, C. E., Karunaharan, A., Lee, J. D., Lewis, A. C., Monks, P. S., Moller, S. J., and Heard, D. E.: Quantifying the magnitude of a missing hydroxyl radical source in a tropical rainforest, Atmos. Chem. Phys., 11, 7223-7233, https://doi.org/10.5194/acp11-7223-2011, 2011.

Whalley, L. K., Blitz, M. A., Desservettaz, M., Seakins, P. W., and Heard, D. E.: Reporting the sensitivity of laser-induced fluorescence instruments used for $\mathrm{HO}_{2}$ detection to an interference from $\mathrm{RO}_{2}$ radicals and introducing a novel approach that enables $\mathrm{HO}_{2}$ and certain $\mathrm{RO}_{2}$ types to be selectively measured, Atmos. Meas. Tech., 6, 3425-3440, https://doi.org/10.5194/amt-6-3425-2013, 2013.

Winiberg, F. A. F., Dillon, T. J., Orr, S. C., Gro B, C. B. M., Bejan, I., Brumby, C. A., Evans, M. J., Smith, S. C., Heard, D. E., and Seakins, P. W.: Direct measurements of $\mathrm{OH}$ and other product yields from the $\mathrm{HO}_{2}+\mathrm{CH}_{3} \mathrm{C}(\mathrm{O}) \mathrm{O}_{2}$ reaction, Atmos. Chem. Phys., 16, 4023-4042, https://doi.org/10.5194/acp16-4023-2016, 2016.

Wolfe, G. M., Crounse, J. D., Parrish, J. D., St. Clair, J. M., Beaver, M. R., Paulot, F., Yoon, T., Wennberg, P. O., and Keutsch, F. N.: Photolysis, $\mathrm{OH}$ reactivity and ozone reactivity of a proxy for isoprene-derived hydroperoxyenals, Phys. Chem. Chem. Phys., 14, 7276-7286, https://doi.org/10.1039/C2CP40388A, 2012.

Zhao, Y. and Truhlar, D. G.: The M06 suite of density functionals for main group thermochemistry, thermochemical kinetics, noncovalent interactions, excited states, and transition elements: two new functionals and systematic testing of four M06-class functionals and 12 other functionals, Theor. Chem. Account., 120, 215-241, https://doi.org/10.1007/s00214-007-0310-x, 2008.

Zheng, J. and Truhlar, D. G.: Quantum thermochemistry: Multistructural method with torsional anharmonicity based on a coupled torsional potential, J. Chem. Theory Comput., 9, 13561367, https://doi.org/10.1021/ct3010722, 2013. 